CUAD. CONTAB. / BOCOTÁ, COLOMBIA, 16 (41): 395-427/ MAYO-AGOSTO 2015/ 395

\title{
Los informes contables anuales y su papel en la institución del "yo" organizacional*
}

doi:10.11144/Javeriana.cc16-41.icap

\section{John Jairo Cuevas-Mejía}

Grupo de investigación Pensamiento y Praxis Contable.

Pontificia Universidad Javeriana, Cali.

Correo electrónico: jjcuevas@javerianacali.edu.co

* Este documento se deriva de la tesis de maestría Los informes contables anuales y su papel en la institución del "yo" organizacional, presentada para optar por el título de magíster en ciencias de la organización, Universidad del Valle, Cali, Colombia, bajo la dirección del profesor Fernando Cruz-Kronfly. Una versión preliminar fue socializada en diciembre de 2014 durante las VIII Jornadas de Sociología, llevadas a cabo en la Universidad Nacional de La Plata, Argentina (http:// jornadassociologia.fahce.unlp.edu.ar/viii-jornadas-2014/PONmesa24Cuevas.pdf/at_download/file) 
Resumen Este artículo se inscribe en la línea argumental de los estudios interdisciplinarios sobre los reportes corporativos, con énfasis en el corporate self, por lo que ahonda en el interrogante: ¿cómo son usados los informes contables anuales para instituir al "yo" de la organización económica moderna en el marco de la contemporaneidad? En consecuencia, desde una perspectiva interpretativa, se acude al psicoanálisis lacaniano junto con la apropiación de categorías conceptuales concebidas al seno de la sociología y la filosofía contemporáneas, para advertir las características en las que se soporta el desarrollo del "yo" y la subjetividad en el espacio de la contemporaneidad. Esto con el fin de hacer inteligible el papel instituyente de los informes contables anuales al margen de la dimensión económica y comunicativa a la que están adscritos hoy. De esta manera, se abordan y caracterizan, con base en el caso de una empresa colombiana, los mecanismos que hacen de los informes contables anuales espejos identitarios en los que se soporta el proceso de institucionalización del "yo" organizacional, al tiempo que cumplen la función de mostrar el texto que hace de las organizaciones económicas modernas como si adviniesen en una suerte de "ciudadanos corporativos".

Palabras-clave "yo"; subjetividad; informes contables anuales; discurso contable; identidad organizacional

\section{Annual Accounting Reports and Their Role in the Creation of the Organizational "Self"}

\footnotetext{
Abstract This article subscribes to the argumentative line of interdisciplinary studies on corporate reports, with an emphasis on the corporate self; such is the reason behind delving into the question: How are annual accounting reports used to create the "self" of the modern economic organization, in the contemporary frame? As a consequence, from an interpretative perspective, we turn to Lacanian psychoanalysis $\rightarrow$ together with the appropriation of conceptual categories created in the bosom of contemporary sociology and philosophy-in order to identify the characteristics on which the development of the "self" and subjectivity are based in the space of contemporaneity. The purpose behind this
}

is to make understandable the constituting role of annual accounting reports beside the economic and communicative dimension they are subscribed to today. In this way, we address and characterize, based on the case of a Colombian company, the mechanisms that make the annual accounting reports mirrors of identity that provide support to the institutionalization of the organizational "self". At the same time, they work showing the text that makes of modern economic organizations as if they became a kind of "corporate citizens".

Keywords "self"; subjectivity; annual accounting reports; accounting discourse; organizational identity

\section{Os relatórios contábeis anuais e seu papel na instituição do "eu" organizacional}

Resumo Este artigo se inscreve na linha argumental dos estudos interdisciplinares sobre os relatórios corporativos, com ênfases no corporate self, pelo que aprofunda o interrogante: como são usados os relatórios contábeis anuais para instituir o "eu" da organização econômica moderna no contexto da contemporaneidade? Em consequência disto, desde uma perspectiva interpretativa, vai-se à psicanálise lacaniana junto com a apropriação de categorias conceituais concebidas no seio da sociologia e da filosofia contemporâneas, para chamar atenção sobre as características nas que se apoia o desenvolvimento do "eu" e a subjetividade no espaço da contemporaneidade. Isto com o fim de fazer inteligível o papel instituinte dos relatórios contábeis anuais à margem da dimensão econômica e comunicativa a que estão adscritos hoje. Desta maneira, abordam-se e caracterizam-se, com base no caso de uma empresa colombiana, os mecanismos que fazem dos relatórios contábeis anuais espelhos identitários nos quais se apoia o processo de institucionalização do "eu" organizacional, ao mesmo tempo em que cumprem a função de mostrar o texto que faz das organizações econômicas modernas como se adviessem em uma sorte de "cidadãos corporativos".

Palavras-chave "eu"; subjetividade; relatórios contábeis anuais; discurso contábil; identidade organizacional 
¿Dónde ahora? ¿Cuándo ahora?

¿Quién ahora?

Samuel Beckett, El innombrable

La contabilidad, la burocracia proceden por calcos; pero también pueden ponerse a brotar, a producir tallos de rizoma, como en una novela de Kafka. Gilles Deleuze y Félix Guattari, Mil Mesetas

\section{Introducción}

Este artículo se propone presentar los argumentos que permitan pensar la emergencia e institución del “yo" de la organización. Para asumir este horizonte de análisis, y tomando como base el trabajo de Sigmund Freud (1988) y Pierre Legendre (2008c) en su análisis de la cultura $^{1}$, se acepta que las organizaciones para constituirse se sirven de medios semejantes a los de los individuos, es decir, son efecto del lenguaje. Así, los informes contables anuales (en adelante, ICA) se asumen como $\mathrm{si}^{2}$ fuesen un isomorfismo del "estadio del espejo" lacaniano, esto es, como formador de la función del "yo"; dicho de otro modo, los ICA instituyen el montaje lingüístico a partir del cual emerge la unidad imaginaria de la organización, su "yo". Este reconocimiento de la organización que subyace en los ICA y que permite conceder-

1 En su examen sobre la cultura occidental, Pierre Legendre (2008c) sigue a Freud (1988) en: “[...] primero tenemos que situar a Occidente desde una perspectiva antropológica, evocando aquí una observación fundamental que tomaré de Freud: El desarrollo de la cultura se asemeja al del individuo y trabaja con los mismos medios" (p. 36).

2 Véanse los trabajos de Legendre (2008a, 2008b, 2008c) alrededor de la función de la institución del "como si", de la cual deriva su análisis antropológico de la cultura occidental. le un "yo", se advierte por la manifestación de formas subjetivas en la organización. Burkard Sievers (1999, 2004, 2005, 2006), sobre la base de lo que él denomina un socioanálisis, elabora la categoría organización psicótica. No obstante, aunque esta referencia resulta de interés para el análisis propuesto, aquí se pretende observar no cómo la organización, en su calidad de tecnoestructura u orden sistémico de representaciones espaciales, produce sujetos psicotizados, sino más bien - y tomando como eje del análisis a los ICA como superficie de inscripción para las identificaciones identitarias-poder marcar algunos rasgos del "yo" de la organización contenidos en el relato que de ella ensambla e instituye la contabilidad en los ICA. Esto es posible si se considera que la organización económica moderna ${ }^{3}$ - al igual que la sociedad y el sujeto-deviene de un ensamblaje discursivo, es producida en un montaje lingüístico que conduce a la lógica de la identidad (Legendre, 2008a, 2008b, 2008c).

\section{Por esta vía, Norman Belding Macintosh} (2002) propone la posibilidad de comprender la estructura de los ICA como un texto. Al centrar el informe anual en su dimensión textual, resulta posible entonces analizar el conjunto de ensamblajes que allí confluyen y que configuran diversas posibilidades de sentidos (formaciones discursivas). Lo anterior reclama aceptar el postulado postestructuralista " $\mathrm{La}$ sociedad no existe" (Laclau, 1990; Stavrakakis, 2007) como vía analítica que desesencializa $a$

\footnotetext{
3 Por razones de espacio y de los alcances de este documento, se sugiere remitirse a un trabajo previamente desarrollado (Cuevas, 2012) en el que se presenta con un mayor énfasis sociológico y una mejor caracterización la emergencia de la organización económica moderna.
} 
la organización económica moderna, permite advertir las diversas capas del ensamblaje de las que está hecha, su dimensión relacional, histórica y contingente. Lejos de recorrer una visión positiva de la organización económica moderna, de suponerla como una totalidad suturada de antemano, el análisis que aquí se propone se decanta por aceptarla constituida como una formación discursiva inscripta en un orden discursivo específico. Así, la organización económica moderna puede ser pensada desde el sintagma "la organización económica moderna no existe”, lo que llama la atención acerca de las formas y mecanismos de inscripción en los que esta se constituye e instituye. Los ICA son, en buena medida, una superficie de inscripción para la formación discursiva que, enmarcada en el orden de discurso de la economía de mercado, se acepta como organización económica moderna. Lo anterior conduce a acoger como recurso analítico no la dimensión positiva de la organización (la cual tampoco está lejos de no depender de un sistema discursivo en donde se le nombra y es pensada), sino aquella formación discursiva que es inscripta en los ICA.

Los ICA no solo movilizan la información sobre los resultados económicos de la organización, sino también sirven como superficie de inscripción para una formación discursiva en diálogo con su entorno (Archel, 2007a, 2007b; Davison, 2011a, 2011b; De Fuentes, 1993; Gómez, 2009; Husillos, 2004). En esta perspectiva, Norman Belding Macintosh (2002) sugiere, sobre la base de la teoría literaria de Mijail Bajtin, comprender a los ICA como un entretejido discursivo, una serie de heteroglosias, de voces y significados, que al final conforman un campo narrativo de la organización.

De esta forma, este artículo busca problematizar la hipótesis de trabajo de que la contabilidad, mediante los ICA, forma e instituye la función del "yo" de la organización económica moderna. En razón de lo anterior se ha debido construir un marco multidisciplinario con el cual pensar la forma de inscripción de la formación discursiva organización económica moderna, es decir, señalar los mecanismos que operan en su ensamblaje. Al considerar que la organización como formación discursiva implica — como en el caso de la cultura, la sociedad y el sujeto- ser efecto de lenguaje, se ha optado por establecer un diálogo con la enseñanza de Jacques Lacan, en particular, las implicaciones de su estadio del espejo, para poder considerar algunos de los mecanismos instituyentes de la contabilidad que la escuela sociológica del pensamiento contable suscribe bajo el sintagma la contabilidad como una práctica social e institucional. Así, este documento está estructurado por esta introducción, seis acápites y un apartado final para las conclusiones provisionales. Por último, con esta orientación se espera contribuir a la comprensión del fenómeno organizacional y contable desde el ángulo de las diversas tensiones sociales e institucionales que lo atraviesan.

\section{Lo simbólico y lo imaginario: diferencias entre yo y sujeto}

El sujeto sujetado al lenguaje, el sujeto del lenguaje en la versión lacaniana, se convierte en una categoría de análisis que potencia la com- 
prensión del surgimiento de la dimensión simbólica e imaginaria en los ICA. En su retorno a Sigmund Freud (Elliott, 1995; Roudinesco, 1993), Jacques Lacan se percata de que la figura del padre no constituye una realidad empírica en cuanto tal, sino, más bien, señala que esta responde a una función en la que es instituida la realidad humana, en donde se produce su montaje (Legendre, 2008c). Derivado de lo anterior, Lacan reconoce que la complejidad de la función paterna es reconocida en sus tres registros: lo simbólico, lo imaginario y lo real. Estos tres registros constituyen el denominado ternario lacaniano, tres registros a partir de los cuales Lacan se aproxima a la comprensión de la función paterna (Chiesa, 2007). Lo simbólico, lo imaginario y lo real se encuentran anudados de tal manera (lo que Lacan en su última enseñanza enuncia como el nudo borromeo), que la desaparición de alguno causa la inestabilidad de los demás, un desanudamiento que conduce al camino de la demencia.

La función paterna, instituida por lo real, lo simbólico y lo imaginario, invoca a creer en el padre. Esto lleva a que Lacan se refiera a "los nombres del padre". La función paterna entonces supone un tipo de orden, de sistema o normatividad atribuida al padre. En el capítulo titulado RSI — real, simbólico, imaginario-, Lacan plantea que "hay tres suposiciones. La primera, o más bien una, es que hay [existe algo], proposición ética que no posee más contenido que su posición misma. Un gesto de corte sin el cual no hay nada que exista. Se llamará eso real o R. Otra suposición es simbólica o S es que hay de 'la lengua', suposición sin la cual nada, ninguna suposición, podría decirse. Fi- nalmente, otra suposición es que existe lo semejante, donde se instituye todo lo que hace lazo. Eso es lo imaginario o I"4. Dicho en otras palabras, el ternario lacaniano supone una estrecha relación entre los términos que lo componen, RSI. La R enmarca el hay, la dimensión ontológica. La S hace referencia a la dimensión simbólica que permite, en esencia, la enunciación; sin ella, nada podría ser dicho. Y, por último, la I, lo imaginario; este es el orden de la similitud, de lo semejante no solo como "el otro", como simple yo especular, sino como todo aquello que tiene el otro y en lo cual el "yo" se proyecta. En síntesis, el ternario lacaniano supone un aporte significativo por parte de Jacques Lacan a la comprensión de la dimensión psíquica del sujeto humano. Al respecto, Lionel Bailly sostiene:

The RSI is not analogous with Freud's model: it does not represent the psyche but a system of interacting realms, orders, or registers in which the psyche functions [...] Lacan's Subject is more abstract - it exists "out there" like a force-field within a universal matrix. The Real, Symbolic, and Imaginary are properties of this matrix [...] the provide a framework for the understanding of the normal functioning of human mind, of psychopathology, and also of all human institutions and creations (2009, p. 88).

\footnotetext{
4 Extracto tomado de un texto inédito de autoría del profesor Anthony Sampson y leído por él durante el desarrollo de la cátedra Psicología Cultural en la maestría en psicología de la Universidad del Valle; esta cátedra se llevó a cabo en el período académico agosto-diciembre de 2013 y en ella participó el autor de este documento.
} 
Si bien la obra de Lacan es bastante amplia en lo que se refiere a su ternario (Assoun, 2003; Chiesa, 2007; Jameson, 1977; Milner, 1996; Muller \& Richardson, 1982; Ogilvie, 1988), para los propósitos de este artículo se hará énfasis en lo imaginario, para captar la institución imaginaria del "yo", como también en lo simbólico, para comprender la emergencia del sujeto (Stavrakakis, 2007).

\section{Lo imaginario en Lacan}

En Lacan, lo imaginario alude a la estructura narcisista del "yo", a la tensión entre el ideal del yo y el yo ideal, como también a la estructura paranoica del "yo" y su desconocimiento (Assoun, 2003; Le Gaufey, 2001). El orden de lo imaginario produce un comportamiento que, orientado por imágenes, se instala por fuera del orden de las necesidades naturales. En síntesis, es orden de la proyección, del transitivismo. Este orden supone el conjunto de identificaciones con el otro; seducido con seductor, esclavo con amo. Visto lo imaginario de este modo, en términos freudianos se estaría haciendo alusión al investimiento libidinal; todo lo que rodea al sujeto humano es susceptible de entrar en el campo imaginario del yo a partir de su investimiento libidinal: la conexión con los otros seres humanos, los animales, las cosas, etc. En este sentido, el registro de lo imaginario concierne al terreno del cuerpo propio en donde predomina lo visual (Le Gaufey, 2001). En consecuencia, lo imaginario implica la emergencia de lo uno, lo uno con el mundo; por intermediación de la imagen el ser humano alcanza su unidad imaginaria (Chiesa, 2007; Pignot, 2012; Rabaté, 2001).
Lo imaginario constituye una fuerza moldeadora de la naturaleza humana. En razón de lo anterior, no debe pensarse lo imaginario como sinónimo de irreal o ficticio; en este sentido, Lionel Bailly indica:

$$
\begin{aligned}
& \text { For an understanding of the Imaginary, we } \\
& \text { must avoid thinking of the world in its com- } \\
& \text { monplace sense of unreal or fictitious [...] } \\
& \text { The imaginary is named for mental process- } \\
& \text { es that issue from the encounter between } \\
& \text { the infant and its image in the mirror [...] } \\
& \text { The Imaginary is the realm of the senses in } \\
& \text { that it houses the conceptions that issue di- } \\
& \text { rectly from sensorial perception (2009, } \\
& \text { pp. 90-91). }
\end{aligned}
$$

Esta concepción del imaginario había sido reforzada por Jacques Lacan (1998) en su famoso seminario sobre los "cuatro conceptos fundamentales del psicoanálisis" según lo advierte en las notas de la publicación al inglés su traductor Alan Sheridan:

The imaginary was then the world, the register, the dimension of images, conscious or unconscious, perceived or imagined. In this respect, 'imaginary' is not simply the opposite of 'real': the image certainly belongs to reality and Lacan sought in animal ethology facts that brought out formative effects comparable to that described in 'the mirror stage' (p. 293).

En esta perspectiva, el sentido de lo imaginario en Lacan supone una enajenación constituyente y constitutiva en razón de que el sujeto 
no se encuentra en sí mismo sino en su imagen especular, en el otro. Así, la enajenación en Lacan supone un encuentro en el otro; esto implica una visión positiva de la enajenación: hay que entregarse, darse al otro para ser. No obstante, el campo de lo imaginario está ausente de cualquier tipo de mediación dialéctica propiamente dicha, esta pertenece al campo de lo simbólico; lo imaginario es el lugar de lo uno o de lo otro. Lo imaginario entonces se expande entre el "yo" y el mundo de las imágenes (Nasio, 2001).

\section{El estadio del espejo 5}

Lo imaginario en Lacan ha sido en gran parte teorizado en su estadio del espejo. $\mathrm{Al}$ respect, Lionel Bailly plantea:

\section{[...] the Mirror Stage is especially important in the development of the Imaginary realm, and because it denotes the crucial moment at which the baby's Subject is 'split' or alienated from itself and takes on its truly human character (2009, p. 90).}

5 Resulta imposible ofrecer una concepción definitiva del estadio del espejo en Lacan, en razón a que su obra consiste en una permanente reelaboración de sus nociones básicas. No obstante, es posible esbozar una cronología inicial de esta teorización: 1936, La fase del espejo, escrito presentado en el congreso de Marienbad, del cual no quedó copia alguna; Más allá del principio de realidad, de 1936 y Los complejos familiares, de 1938, constituyen dos iniciativas en torno a la formación del "yo"; el texto conclusivo de esta primera etapa es El estadio del espejo como formador de la función del yo(je), presentado en 1949 en el XVI Congreso Internacional de Psicoanálisis en Zurich. Esta última versión ha sido traducida al español por Tomás Segovia e incorporada en los Escritos publicados por la editorial Siglo XXI. Siguiendo a Dany-Robert Dufour (2005), el estadio del espejo como teorización hace que Lacan se convierta en Lacan. Véase también Élisabeth Roudinesco (1993).
El estadio del espejo constituye un paradig$\mathrm{ma}^{6}$. En este sentido, más allá de lo universal o particular, instala la regla, la norma en sí. Al respecto, Lacan sostiene:

El estadio del espejo es un drama cuyo impulso interno se precipita de la insuficiencia a la anticipación y que, para el sujeto, engañado por la ilusión de la identificación espacial, urde las fantasías que se suceden desde una imagen fragmentada del cuerpo hasta una forma que llamaremos ortopédica de su totalidad (1984, p. 90).

Visto de esta manera, el estadio del espejo hace posible comprender la formación de la función del "yo" que, tal como la concibe Lacan, adviene como armadura que integra la unidad imaginaria. Así, el estadio del espejo supone una dialéctica entre el individuo y el otro, su imagen en el espejo (Chiesa, 2007). En consecuencia, el "yo" para Lacan es fruto de la alienación imaginaria, resultado de la identificación a partir de la cual el sujeto se transforma al asumir una imagen y reconocerse en ella (Dasuky-Quiceno, 2010).

En oposición a la corriente de la "psicología del yo", Lacan propone un punto de vista en esencia reaccionario respecto del entendimiento del "yo" (Elliott, 1995; Lacan, 1984; Roudinesco, 1993). Para Lacan (1984), el “yo" es ortopédico en la medida en que se ubica en el registro de lo imaginario, es una imagen, una ficción, con la que el sujeto se identifica y desde la

6 Para comprender la dimensión del concepto de paradigma, se remite al lector al trabajo ¿Qué es un paradigma?, de Giorgio Agamben (2009). 
cual es in-formado y guía su desarrollo (Muller $\&$ Richardson, 1982). Las bases en las que se apoya Lacan (1984) y que lo llevan a sostener que el "yo" es una imagen que transforma al sujeto que la asume, son variadas. Dufour (2005) ha identificado al menos cinco bases de interés alrededor del estadio del espejo:

1. El narcisismo

2. El neodarwinismo

3. La psicología de la Gestalt

4. El fenomenología hegeliana

5. La teosofía de Jacob Böhme ${ }^{7}$

Estos cinco aspectos podrían sintetizarse en el rechazo de Lacan a la comprensión del "yo" a partir de una filosofía del cogito, es decir, a una filosofía cartesiana en la cual el "yo" es por completo transparente a sí mismo. El "yo" para Lacan está lejos de ser cartesiano, una especie de fruto del pensamiento. Esta es la razón por la cual Lacan (1984) refiere un desconocimiento en la experiencia en el espejo; "el yo no sabe, desconoce, entonces que forma parte de la imagen y que la imagen forma parte de él" (Nasio, 2001, p. 30). La virtualidad de la imagen especular instala en el sujeto la unidad total que reemplaza la experiencia fragmentada de su cuerpo ${ }^{8}$. En esta medida, el sujeto alcanza

7 Como no es el interés realizar un excurso acerca de la historia del estadio del espejo, se remite al lector a los trabajos de Dany-Robert Dufour (2005) y Guy le Gaufey (2001) pues ofrecen una interesante perspectiva acerca de los fundamentos del estadio del espejo. Guy Le Gaufey (2001) agrega a las fuentes señaladas por Dufour (2005) la metafísica de Edmund Husserl.

8 En el caso del infant, previo a la etapa del estadio del espejo que se presupone entre los ocho y los 18 meses, la experiencia de su cuerpo es fragmentaria, en parte, por el precario desarrollo de su sistema nervioso central. la conquista de su identidad a partir de la imagen vivida como imagen del otro, luego asumida como propia (Dor, 1994). Este origen del "yo" lleva a Lacan a considerar el núcleo paranoico que toma forma en cada sujeto (Fink, 1999). Esta paranoia constitutiva se explica en la reformulación de Lacan del clásico axioma cartesiano: "Pienso, luego existo". La experiencia del espejo lleva a Lacan a sugerir, por el contrario, un nuevo axioma para la recomposición del sujeto cartesiano "no pienso ahí donde soy, no soy ahí donde pienso" (Dufour, 2005). El sujeto no es la imagen que el espejo le retorna; esa imagen no asume la realización del cogito, ella es pura virtualidad. Por tanto, la función del estadio del espejo es instituir el lazo especular, hacer lazo con el semejante, instituir lo uno (Le Gaufey, 2001). En síntesis, el estadio del espejo lacaniano constituye un punto importante en la comprensión del desarrollo de la naturaleza humana. Al respecto, Sean Homer refiere que:

$$
\begin{aligned}
& \text { Lacan's innovation in 'The Mirror Stage' } \\
& \text { was to combine the phenomenological dis- } \\
& \text { tinction between subject and ego with a } \\
& \text { psychological understanding of the role of } \\
& \text { images and the constructed nature of the } \\
& \text { self through the philosophical category of } \\
& \text { the dialectic (2005, p. 22). }
\end{aligned}
$$

Esta dialéctica que se deriva del espejo implica la relación del sujeto con la imagen especular. La forma alcanzada por el sujeto a partir de la identificación con la imagen, instituye la armadura yoica garantizada por sus mecanismos de defensa. El yo es otro al que alude el poeta Arthur Rimbaud hace sentido a la con- 
cepción del "yo" elaborada por Lacan, su naturaleza ficcional (Muller \& Richardson, 1982).

En este orden de ideas, el "yo" está envestido de imagen, es la imagen. En consecuencia, el "yo" adviene como el campo que se forma entre la persona delante del espejo y la imagen especular. No obstante, las imágenes que son el mundo del "yo" son las imágenes en las que él se reconoce (Nasio, 2001). Esto exige precisar un aspecto que resulta central a la concepción del estadio del espejo: el yo ideal. El sujeto, al precipitarse en la imagen del espejo, lo hace por la vía del reconocimiento y de la identificación, pues la imagen está cargada de idealidad yoica, es decir, lo que el “yo” espera:

...el Yo Ideal es la dimensión esperada del yo, de reconocerse como él esperaría reconocerse. Lo que él espera, lo que él quiere [...] Es la suposición esperada del yo cuando se reconoce en la imagen. Eso es el Yo Ideal (Nasio, 2001, p. 35).

En este sentido, el yo ideal orienta al "yo" por la vía de la ficción. Esto ocasionará, en consecuencia, una discordancia entre el "yo" y la realidad del sujeto (Muller \& Richardson, 1982). Visto así, la sustancia imaginaria que es el "yo" no resulta en modo alguno homologable a la categoría de sujeto. Mientras el "yo" está relacionado con las imágenes y deviene a partir del yo ideal, el sujeto está relacionado con el Otro, el lenguaje, la ley de la cultura, por lo que se instituye a partir de los ideales del yo. Si el "yo" deviene como forma ortopédica que da unidad a la realidad fragmentada del cuerpo, anclado a la dialéctica especular en la que se enmarca su campo sometido a las reglas de lo imaginario, el sujeto adviene como efecto del lenguaje (Ogilvie, 1988). Si lo imaginario instituye el lazo binario entre el "yo" y su imagen especular, lo que hace del "yo" lo objetivo, lo simbólico instituye lo ternario, inserta al sujeto en el campo del Otro que instituye lo subjetivo (Dufour, 1990).

\section{Sujeto y lenguaje desde la perspectiva de Paul Ricœur}

Si bien para el análisis propuesto se ha construido un acervo teorético que permita pensar la institución del "yo" de la organización por medio de los ICA, resulta conveniente matizar al sujeto sujetado al lenguaje (Dufour, 2007), y el lenguaje del que este se sirve para articularse (sujetarse) con su contexto cultural y social, en atención del anudamiento entre los registros imaginario y simbólico en Jacques Lacan (1977). Si el estadio del espejo instituye la función del yo (je), el lenguaje oculta al sujeto en el sujeto del lenguaje; por esta razón, otras analíticas permiten comprender la naturaleza del sujeto que a partir del lenguaje se tornan relevantes. En este sentido, se ha recurrido a Paul Ricœur, filósofo francés que dedicó parte de su obra a la teoría hermenéutica y a los conflictos que de ella se derivan. Esta elección, por sobre otras posibles y sin desconocer el desarrollo de Lacan respecto del sujeto en falta como sujeto del inconsciente (Lacan, 1984), se debe a la conceptualización que sobre el lenguaje y el sujeto Ricœur entrega y que se corresponde con las preocupaciones esbozadas hasta aquí. “El lenguaje es en sí el proceso por el cual la 
experiencia privada se hace pública", sostiene Ricœur (2006b, p. 33), esta idea señala que el lenguaje no se agota en la mera significación de la realidad sino que, en esencia, se concreta cuando por su medicación algo es puesto en evidencia, des-velado. Así, Ricœur (2006b) afirma que "las lenguas no hablan, las personas sí".

Sin embargo, como se ha propuesto una mirada en torno a cómo la organización económica moderna se despliega en otra en la superficie de inscripción instituida por el lenguaje contable, algunas de las tesis de Paul Ricœur en su obra, en especial en su libro "Sí mismo como otro", entregan un marco teórico de interés: la hermenéutica del sí como una filosofía del lenguaje. Tanto en su sentido semántico como pragmático, la filosofía de la acción relaciona los “¿quién habla?” y "quién actúa”, para al final entrar a caracterizar las polisemias del ser y de la alteridad.

No obstante, para Ricœur, el proceso de individuación está relacionado con y determinado por el lenguaje, en la medida en que este lo hace posible. En tal sentido, Ricœur afirma:

La individuación puede caracterizarse, en líneas generales, como el proceso inverso al de la clasificación, que elimina las singularidades en provecho del concepto. Pero, si recalcamos principalmente el adjetivo "inverso", acentuamos solo dos rasgos negativos del individuo: que es una muestra no repetible y, además, no divisible sin alteración; estas negaciones nos llevan, en efecto, del lado de lo inefable. Ahora bien, no porque el movimiento sea inverso queda el lenguaje despojado, como si se agotase en clasificar y caracterizar por medio de predicados. El objetivo individualizador comienza allí donde cesan clasificación y predicación, pero se apoya en estas operaciones y, como veremos, las reactiva. No se individualiza más que si se ha conceptualizado e individualizado con intención de describir más (2006a, p. 2).

Por esta razón, siguiendo con Ricœur, la función del lenguaje se caracteriza de muy particular modo tras el proceso de individuación, por ello afirma:

$$
\begin{aligned}
& \text { El lenguaje debe reparar, en cierto modo, la } \\
& \text { pérdida consumada por la conceptualización, } \\
& \text { precisamente porque pensamos y hablamos } \\
& \text { mediante conceptos. Pero no emplea, con } \\
& \text { esta finalidad, los mismos procedimientos } \\
& \text { que aquellos mediante los que conceptuali- } \\
& \text { za, es decir, la predicación (2006a, p. 2). }
\end{aligned}
$$

De esta manera, para Ricœur, el sujeto consiste en los actos de enunciación tras los que este se configura, en especial el énfasis recae sobre el acto enunciativo del "yo". En consecuencia, el acto de enunciación contempla lo siguiente:

$$
\begin{aligned}
& \text { Puesto en relación con el acto de enuncia- } \\
& \text { ción, el "yo" se convierte en el primero de } \\
& \text { los indicadores; indica a aquel que se de- } \\
& \text { signa a sí mismo en toda enunciación que } \\
& \text { contenga la palabra "yo", llevando tras él el } \\
& \text { "tú” del interlocutor. Los demás indicadores } \\
& \text { —los deícticos: "esto", "aquí", "ahora”- se } \\
& \text { reagrupan en torno al sujeto de la enuncia- } \\
& \text { ción: "esto" indica todo objeto situado en la }
\end{aligned}
$$


cercanía del enunciador; "aquí" es el lugar mismo en que este se encuentra; "ahora" designa todo acontecimiento contemporáneo de aquel en el que el enunciador pronuncia la enunciación (Ricœur, 1999, pp. 24-25).

En este sentido, la idea de discurso cobra importancia para Ricœur en la medida en que constituye el acontecimiento del lenguaje. Los actos de habla son los que forman, configuran y entretejen al discurso; a esto se debe que el discurso tenga la forma de " $[. .$.$] el entrelaza-$ miento y la acción recíproca de las funciones de identificación y predicación en una y la misma oración” (Ricœur, 2006b, p. 25).

El sujeto que se produce a partir de los actos de habla (el sujeto sujetado al lenguaje en la versión de Lacan), en la idea que desarrolla Ricœur, está matizado por la fuerza del acontecimiento, es decir, por el discurrir en el tiempo en que es producido ya sea el acto locutivo (decir algo), el acto ilocutivo (hacer algo al decir algo), o el acto perlocutivo (producir efectos al decir algo). El acontecimiento, entonces, toma la forma de:

[...] no solamente es la experiencia tal como es expresada y comunicada, sino también el intercambio intersubjetivo en sí, el acontecer en el diálogo. La instancia del discurso es la instancia del diálogo. El diálogo es un acontecimiento que conecta dos acontecimientos, hablar y escuchar (Ricœur, 2006b, p. 30).

La idea que subyace al sujeto y sus actos de habla, está atravesada por el diálogo en su acontecer como discurso. Esta concepción del sujeto en los marcos del lenguaje, es decir, que su existencia está condicionada por los actos de habla (Ricœur, 2006a) o por el lenguaje en que este se estructura (Lacan, 1984), determina la forma en que puede o no ser entendido el "yo" de la organización al tomar una posición como sujeto que encuentra su existencia en el lenguaje. La organización que se instituye en los ICA, aquella que está condicionada por el relato que utiliza la contabilidad para producirla, está condicionada por la dinámica que en la cultura asume el lenguaje. Si "la organización económica moderna no existe”, esta debe ser producida, por lo que los ICA se develan como superficies de inscripción para la formación discursiva organización económica moderna, la cual se fija - no obstante sujeta a su dimensión histórica y contingente-en cada acontecimiento de discurso.

En esencia, todo sujeto por estar sometido a un otro, necesita de un "tú" para constituir y afirmar su "yo" (Dufour, 2007; Taylor, 2006; Žižek, 2004). En el marco de esta relación, el sujeto para afirmar su "yo" necesita de un "tú", es decir, de un Otro/otro que, aunque le imponga resistencia, se muestra necesario en el sentido de lo enunciado por el poeta Rimbaud: " $y o$ es otro". Dicho lo anterior, el proceso de aparecimiento de la instancia psíquica denominada "yo" requerirá siempre del lenguaje, un lenguaje en el que se inscribe su relación con la alteridad. Así, la organización económica moderna encuentra en los ICA no solo el medio para revelar información, sino que es constituida en ese mismo movimiento como organización económica moderna, aunque desconozca el lazo que hace con la imagen. 


\section{Del "yo" de la organización y su institucionalización en los informes contables anuales (ICA)}

Norman Belding Macintosh (2002) propone ver en los informes anuales una suerte de narrativa acerca de la organización. La contabilidad produce una formación discursiva en la que se ensamblan no solo las condiciones socioeconómicas, sino las relaciones de identidad que fijan a la organización económica moderna al orden de discurso dominante. Esta formación discursiva que se fija a la espacialidad física o virtual de los informes, para el caso de la información financiera, facilita la articulación del conjunto de identificaciones en favor de la aceptación social del imaginario organizacional. En este orden de ideas, el discurso contable está sujeto a un orden social desde donde es producido 9 .

Pensar el orden de discurso articulado en los ICA, en esencia, exige aceptar que este es expresado desde un punto o lugar de enunciación. Este lugar es la organización económica moderna, cuyo núcleo está enlazado a los sig-

9 Si bien hay corrientes de pensamiento contable sumamente interesantes (Mattessich, 2002) que trabajan a partir de constructos abstractos de la contabilidad, es decir, en su dimensión epistemológica, aquí toma mayor interés, más bien, la dimensión social de las categorías contables. Dicho de otro modo, el ángulo desde donde se sitúa la ontología de los informes anuales, para el caso de análisis que aquí se propone, es el social. Por tanto, se acepta el argumento de Peter Miller (1994) y de Stuart Burchell, Colin Clubb, Anthony Hopwood, John Hughes y Janine Nahapiet (2005) acerca de que la contabilidad es una práctica social institucionalizada. nificantes racional, responsable y moderna ${ }^{10}$. De esta manera, la organización no puede ser comprendida por fuera del ámbito institucional desde donde se configuran sus prácticas organizacionales. Lo anterior implica reconocer que el orden del discurso contable está vinculado al ámbito institucional en donde se forman los enunciados ${ }^{11}$ que se movilizan en la superficie de inscripción de los ICA. En este sentido, deberá reorientarse la comprensión acerca de la dimensión ontológica de los ICA. Dicho de otro modo, tendrá que advertirse en ellos una naturaleza situada más allá de lo económico; concebirlos no solo como un bien económico, sino como texto (Macintosh, 2002).

En el orden del discurso contable se hace visible $a$ la organización de la que no solo se predica (el predicado), sino también es sujeto de la enunciación y del mensaje que allí subyace. Los informes anuales, en atención a su rol comunicativo (Davison, 2011a, 2011b; Macintosh, 2002; Preston, Wright \& Young, 1996), tornan visible la idea que de sí posee la organización. Reconocer la contabilidad como estructuradora de discurso (Archel, 2007a, 2007b), al aceptar que este no es otra cosa que la ideologización de las formas del lenguaje como lo advierte Ricœur (1989), vislumbra

10 Lejos de constituir una apología, con estos significantes se busca demarcar el resultado de la interpelación que la ideología de la globalización de mercado realiza sobre la forma empresa, y el lugar que en su posición de sujeto le asigna: responsable, racional y moderna.

11 Provisionalmente, debe entenderse el enunciado como "el espacio común donde se construyen y evidencian las fuerzas enunciativas, ofrece una explicación de la construcción tridimensional del sujeto discursivo: axiológico (Ethos), emotivo (Pathos), razonable (Ratio)" (Martínez, 2005, p. 11). 
también que las formaciones discursivas ${ }^{12}$ que asume lo contable delinean una realidad a la que, al menos de manera directa, es difícil de acceder. Por tanto, la formación discursiva que se ensambla en los ICA asume $a$ la organización como eje del relato. En consecuencia, Norman Belding Macintosh (2002) en este sentido propone pensar los ICA a la manera de una novela.

Esta visibilización de la organización económica moderna a partir del discurso contable, potencia su caracterización como un agente racional. No obstante, el discurso inscripto en los informes no solo está al servicio de tal propósito. Alistair M. Preston, Christopher Wright y Joni J. Young (1996), siguiendo las diferentes tendencias del arte contemporáneo, han develado el papel que han pasado a desempeñar las imágenes en los ICA. Las imágenes no se sitúan en la superficie del informe de manera neutral, sino que, más bien, cumplen un papel central en la medida en que potencian el ejercicio de constitución/ afirmación de la identidad de la organización. $\mathrm{Al}$ respecto, Alistair M. Preston, Christopher Wright y Joni J. Young (1996) señalan:

Instead, annual reports are a visual medium through which corporations, one of the principal political, social, and economic institutions of the twentieth century, attempt to

12 Las formaciones discursivas que asume lo contable están ubicadas entre el límite espacial de los informes anuales. Por un lado, en términos del texto, podrían mencionarse el informe de gestión, la memoria anual, la carta del presidente a los accionistas, el informe de auditoría, las notas a los estados financieros; y por el otro, en términos del paratexto, imágenes con cifras ejemplarizantes, imágenes con lema corporativo, premios y certificados, epígrafes, títulos resaltados, encabezados, pie de páginas, etc. represent and, as we shall argue, constitute themselves (p. 115).

En tal sentido, los ICA desempeñan un papel comunicativo de especial relevancia en la medida en que entretejen resultados económicos, al tiempo que en ellos se suceden una serie de elementos, en mayor proporción ubicados en el orden de lo paratextual, que se articulan de tal forma en función de favorecer la constitución de la identidad organizacional. Así, las narrativas que se proyectan en los ICA reflejan y constituyen la realidad de las organizaciones. Por su parte, Jane Davison (2011a), siguiendo un análisis basado en la semiótica de Roland Barthes, ha llamado la atención sobre el papel de las imágenes y otros paratextos en los informes anuales, al resaltar que:

Accounting has always incorporated words as well as numbers, but the role of narratives has increased substantially in recent years, whether through mandatory or voluntary disclosures, and this has extended to social and environmental reporting; all such narratives may be analyzed for their denotations and connotations. From a visual perspective, numerical financial statements may themselves be regarded as visual artefacts which both denote and connote, but beyond the financial statements, accounting and accountability reports incorporate an eclectic mix of graphs, photographs and pictures, all of which entail rich connotations as well as denotation (2011a, p. 255). 
Desde este punto de vista, los informes anuales son un poderoso dispositivo, cuya potencia radica en su capacidad para construir/ producir una superficie de inscripción de amplia legitimidad social a la que adviene la formación discursiva de la organización. Los diferentes tipos de signos que se hacen presentes en los informes anuales, palabras (frases o párrafos), números, gráficos, efectos de diagramación, imágenes y pinturas, estructuran e instituyen este campo de la significancia. Por esta razón, se reconoce la capacidad de la contabilidad, de manera más puntual en su rol como información financiera (Sunder, 2002), de estructurar el orden organizacional ${ }^{13}$. Al respecto, la capacidad que posee la contabilidad para crear $y$ visibilizar un orden organizacional (Burchell, Clubb \& Hopwood, 1985), viabiliza la materialización del vínculo de la organización con su entorno. Dicho de otro modo, desde tal orden, surgen la organización y su vínculo con la sociedad. Esto implica que el mensaje arraigado en los ICA constituye a la organización al tiempo que la incorpora a la esfera de lo social como un agente activo.

Estas formaciones discursivas articuladas en los ICA, principalmente del lado de las imágenes, devienen del dominio que la imagen ejerce en la cultura contemporánea. George Steiner (1991) en su análisis sobre los cambios que

13 La importancia de los informes contables ya había sido advertida por Anthony Hopwood (1996). A mediados de la década de los 90, en la nota editorial de la revista Accounting, Organizations and Society, 21 (1), Hopwood llamaba la atención sobre el papel de los informes contables en la intervención y visibilización de la realidad de las organizaciones. En este sentido, señalaba la necesidad de generar mayores y mejores aproximaciones investigativas a ese campo de enormes tensiones que son los informes contables. acontecieron sobre la Cultura Occidental posteriores a la Segunda Guerra Mundial, prevé el dominio de la imagen sobre la palabra. Con esta mirada, en Occidente ha tenido ocurrencia la denominada crisis del lenguaje, un fracaso de la palabra en su poder de representar la realidad humana. El ingreso al mundo contemporáneo se ha realizado por medio de una conciencia que se devela independiente de los recursos del lenguaje; al menos de esta manera concibe George Steiner (1990) el ingreso en la contemporaneidad:

[...] la conciencia occidental se independiza de los recursos del lenguaje para ordenar la experiencia y dirigir los negocios del espíritu, las palabras mismas parecen haber perdido algo de su precisión y vitalidad (p. 50).

La crisis del lenguaje, como una crisis de la palabra (Steiner, 1990), dio apertura en el siglo XX al denominado giro lingüístico. Jane Davison (2011a) relaciona las implicaciones de este fenómeno en torno al lenguaje en el siglo XX y sus alcances en la contabilidad. Este giro lingüístico ha hecho posible distinguir en los ICA su enorme importancia frente al proceso de hacer visible $a$ la organización. Esta idea de lo visible le permitió a Alfred W. Crosby (1998), tras el surgimiento de la contabilidad por partida doble en la Italia renacentista, señalar el papel de la contabilidad no solo por su dinámica asociada a la pantometría, es decir, aquel afán por medir todo que conquistó al pensamiento en Occidente a partir del año 1250, sino por el mundo que a partir de ella pudo empezar a hacerse visible. De esta manera, el poder de los 
cálculos contables hizo posible observar una realidad que no es directamente observable.

Este poder de visibilidad que descansa en el orden del discurso de la contabilidad pone a las organizaciones bajo control. No obstante, más allá del poder de los cálculos contables, estos tienen un impacto considerable sobre la construcción de imaginarios manageriales. En este sentido, si se considera la capacidad de medición de la contabilidad, por ejemplo, la medición del beneficio por medio del estado de resultados, se produce una imagen de eficiencia operativa o de eficiencia marginal que se instala en el imaginario de la organización, lo coloniza. Esta forma en que la contabilidad presenta la obtención del beneficio ayuda a producir la imagen en la que el beneficio aumenta el capital. Por tanto, es la contabilidad la que produce y visibiliza la idea que conquista a la organización acerca del beneficio.

Por consiguiente, los ICA como superficie de inscripción de lo contable, condensan un conjunto de imágenes a partir de las cuales se produce $a$ la organización. En efecto, en la actualidad se evidencia el cada vez más activo papel de lo visual en los ICA. Paolo Quattrone (2009), en relación con el poder de lo visual, sostiene:

[...] It is thanks to this visual power of (physical and virtual) inscriptions and to their analytical organization in a virtual space (which, in the case of this paper, takes the form of early modern accounting books) that accounting can be practiced and thus appropriated by the user. It aims to illustrate how these visual representations offer a possibi- lity for performance beyond the persuasive communication of a given message that these images convey (pp. 88-89).

Los estudios visuales en contabilidad se han ocupado, en gran medida, de abordar el papel de las imágenes, los gráficos, las fotografías y las palabras, entre otros aspectos visuales ${ }^{14}$ (Davison, 2007, 2010, 2011a, 2011b; Davison \& Skerratt, 2007). Estos dispositivos visuales no solo se ponen al servicio del mensaje que los ICA buscan movilizar, sino que además, como sostienen Alistair M. Preston y Joni J. Young (2000), permiten constituir a la organización al producir el conjunto de imágenes a partir de las cuales ella proyecta su identidad. En esta medida, el poder de lo visual en la contabilidad descentra la importancia asignada a la información como un mecanismo de comunicación de información confiable, y más bien se orienta a examinar los efectos que la contabilidad y sus técnicas (Balanced Scorecard, Mapas Estratégicos e, incluso, los Estados Financieros) producen sobre los actores organizacionales. En consecuencia, existe una capacidad retórica y visual de la información emplazada en la contabilidad para imaginar a las organizaciones; desde esta perspectiva, Paolo Quattrone (2009) retoma un aspecto central del pensamiento medieval con relación a los números:

We are back to a kind of medieval worship of numbers as figures, of devote images which need to be liturgically experienced (p. 112).

14 Por ejemplo, los aspectos de diseño de los ICA. 
Así, esta mirada asume las cifras contables como figuras, imágenes constitutivas. En consecuencia, se orientan como una forma que in-forma a la organización sobre sí misma. El papel de las imágenes como forma que in-forma, ha sido destacado por el psicoanálisis de orientación lacaniana en razón de su contribución a la constitución del sujeto humano. John P. Muller y William J. Richardson (1982, p. 34) proponen comprender el "estadio del espejo" de Lacan como el momento en el cual "the subject is in-formed by his own image, is captivated by the other's image, and objects themselves take on the rigid features of the ego". Lacan (1984), de la mano de una consideración positiva de la alienación, supone que el sujeto llega a ser en la medida en que pierde algo y asume de forma ortopédica la imagen del espejo, el otro en quien se aliena. El estadio del espejo lacaniano constituye una identificación con la cual el sujeto se transforma, pues el infant ${ }^{15}$, quien permanece bajo una experiencia fragmentada de su cuerpo, se precipita en la imagen (el otro) y anticipa una forma que aún no es: la unidad del cuerpo (Lacan, 1984; Muller \& Richardson, 1982). En consecuencia, es posible proponer un isomorfismo ${ }^{16}$, al menos con fines analíticos, entre los ICA y el estadio del espejo lacaniano sobre la base de la anticipación y la precipita-

15 Para el psicoanálisis, el infant constituye la etapa humana aún ausente de la dimensión simbólica, es decir, del lenguaje.

16 Se sigue aquí el análisis que realiza Dufour (1990) para establecer un isomorfismo entre la trinidad de los pronombres personales y el triángulo pragmático (instrucción pragmática) del mito. A partir de esto, evidencia la correspondencia en la estructura lógica entre estas dos conceptualizaciones provenientes de campos discursivos diferentes. ción a la que conduce la unidad imaginaria, en este caso con la imagen que instituye la contabilidad acerca de la organización. Alfred W. Crosby (1998) a propósito refiere:

Matthäus Schwartz, contable de los Füger en el siglo XVI, dijo [de la contabilidad por partida doble] que era un espejo mágico en el cual el adepto se ve tanto a sí mismo como a los demás (p. 167).

Más allá del recurso explicativo de la metáfora en Alfred W. Crosby (1989) para comprender el papel de la contabilidad en la Italia renacentista, aquí se asume hasta las últimas consecuencias tal enunciado. Por tanto, la contabilidad en su dimensión como lenguaje produce e instituye, en su carácter de práctica social e institucional, al “yo” de la organización.

Así, cada vez que la organización adviene al espejo de la contabilidad como un lenguaje, se instituyen imágenes en las cuales esta se enajena, imágenes de un otro producido por la formación discursiva contable en la que la organización se reconoce; se está indicando que tras ese acto se produce un otro de hecho diferente de la organización, se hace lazo con el semejante. Esto permite sostener que, en un ámbito institucional confeccionado por Grandes Sujetos —al decir de Dufour (2007) ${ }^{17}$ — el "yo" de la organización ensamblado por el discurso de la contabilidad como lugar en que es instituido, siempre "es otro", una imagen con la que la organización hace uno.

17 Se hace alusión fundamentalmente a la modernidad en la cual identifica Dufour (2007) a diversos Grandes Sujetos. 
Así como Lacan plantea en el estadio del espejo una suerte de desconocimiento del "yo", en la medida en que este no sabe que es la imagen, puede señalarse que para el caso de la organización el poder constitutivo del discurso contable tiene como efecto que la organización desconozca que es ella quien yace en la imagen que la contabilidad despliega. Si el "yo" es ortopédico al sujeto, es porque le provee la imagen de la totalidad de la cual carece; el "yo" organizacional ensamblado en el orden de discurso de la contabilidad y desplegado en los ICA logra dotar a la organización de una imagen de la totalidad que esta no posee: los ICA constituyen una suerte de imagen ortopédica de la organización, su imagen como organización económica moderna.

Dicho lo anterior, las imágenes ${ }^{18}$ de los ICA deberán ser leídas teniendo en cuenta a quién van dirigidos y cuál es el interés o el significado predominante que se descifra en la lectura textual del informe, ya que estos ante todo intentan producir un efecto como resultado de la forma documental del informe (dado su carácter institucional) que instituye las circunstancias en que está la organización. Por esta razón, los ICA no solamente facilitan el conocimiento común de los aspectos económicos (Sunder, 2002), sino también se ponen al servicio de hacer visibles los aspectos que componen y estructuran la realidad de la organización. En consecuencia, el contenido de los informes dinamiza el ensamblaje de la

18 Para entender el papel de las imágenes en los informes y posteriormente emprender su análisis es necesario superar una vieja forma de pensar acerca de las imágenes como un elemento que ilustra un texto (Burke, 2001). identidad de las organizaciones económicas modernas, y las imágenes que los componen no fungen como un elemento decorativo de estos, sino, en esencia, connotan el sentido que reposa en el discurso contable de los ICA; dicho de otro modo, las imágenes en los ICA cumplen un papel constitutivo de la organización (Preston \& Young, 2002), lo que en términos de la orientación lacaniana implica el montaje del "yo" al articularse la organización por la vía de la identificación con las imágenes que le son enseñadas en los ICA. Así, los ICA no son otra cosa que la unidad imaginaria de la organización, advienen como su espejo identitario, un pliegue de esta.

Vista así, "la organización económica moderna no existe" permite develar la manera en que una organización ingresa en la lógica de la identidad, de los intercambios con la alteridad. Si se acepta este sintagma, cuyo origen se remonta a la manera en que Ernesto Laclau (1990) deconstruye la visión esencialista de la sociedad, es posible advertir que la organización en modo alguno posee una esencia y mucho menos constituye una realidad positiva. De esta manera, la perspectiva seguida hasta aquí se ha propuesto considerar la forma en que la organización es ensamblada por mediación de los ICA, cómo estos constituyen una superficie en la que se inscribe la formación discursiva organización económica moderna en respuesta a un orden discursivo que la interpela bajo la forma racional, responsable, moderna. En el siguiente acápite se desarrollará un caso que, más allá de su singularidad, permite extraer conclusiones a partir de las cuales tensar lo que hasta el momento se ha elaborado. 


\section{El caso Bancolombia: la institucionalización de una "Banca más humana"}

Se pretende ilustrar a partir de un caso la forma en la que los ICA operan en la institución del "yo" organizacional. La lectura del informe seleccionado se dio bajo dos perspectivas; la primera $^{19}$, con base en el método iconológico de Erwin Panofsky (2008), diferencia tres momentos: preiconográfico, iconográfico e iconológico; y la segunda articuló la lectura del componente visual con la identificación de los enunciados asociados a las categorías que anudan lo imaginario y lo simbólico en Lacan: 1) “Formas del deseo (Yo ideal)", esta categoría permite identificar enunciados que respondan a formas ideales sin mediación simbólica, y 2) "Declaración de principios y valores", esta categoría permite señalar enunciados que apuntan a la suscripción de un ethos; por tanto, en este terreno se hace presente la mediación simbólica. Para realizar esta tarea, se ha optado por usar el Informe Gestión Empresarial Responsabilidad Corporativa, de 2011, del Grupo Bancolombia, uno de los conglomerados financieros con mayor presencia en Colombia y América Latina. En la actualidad, esta compañía está listada en el Índice Dow Jones de Sostenibilidad y como entidad financiera colombiana está listada en la Bolsa de Nueva York (NYSE). Para 2011, esta compañía adoptó como principio fundamental ser una Banca más humana.

19 Este apartado no podría haberse logrado sin los valiosas aportes de John Ordóñez, artista visual quien contribuyó a la construcción de esta narrativa visual.
Este sintagma buscó instituir la imagen antropomórfica de la organización al margen de las preocupaciones por la rentabilidad en la cual su praxis siempre hace eje. El relato que sigue busca recorrer, por despliegue, la operación de articulación/identificación a la que conduce la conformación imaginaria del "yo" de la organización:

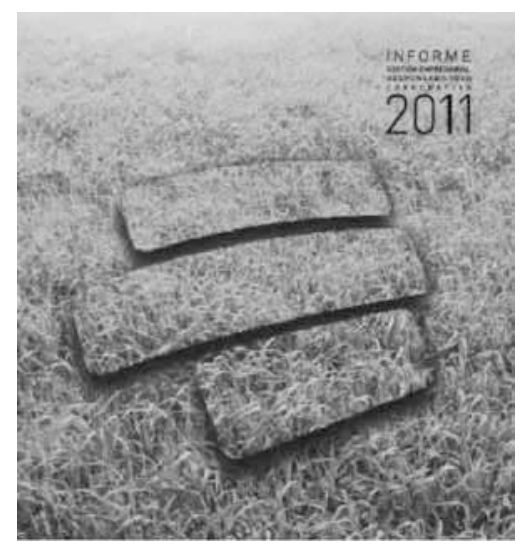

Fuente: Bancolombia (2011). Informe Gestión Empresarial Responsabilidad Corporativa, p. 1.

La imagen que da inicio a este informe muestra un logo que sobresale de un espacio natural mediante un efecto visual en que el verde de la naturaleza da forma al logo, en un juego visual que intenta asociar las ideas de esperanza y tranquilidad que coinciden con el mensaje de la diagramación final del informe en la que se citan unos valores que se asocian con la idea de una "banca más humana".

A partir de 2011, Bancolombia implementó la estrategia económica que denominó "Una banca más humana”, para la cual estableció un diccionario de valores (En el informe, Bancolombia propone los siguientes significantes: calidez, cercanía, cliente, coherencia, com- 
promiso, confianza, conversar, crecimiento, eficiencia, gratitud, honradez, humildad, inclusión, innovación, rentabilidad, respeto, sostenibilidad y transformación). En este caso, esta estrategia se convierte en eslogan de una campaña publicitaria, que en esta imagen (collage) retoma recortes de periódico que intentan mostrar el reconocimiento público que obtuvo la iniciativa. En esta imagen, la mayoría de los recortes no tiene fecha de publicación y en el uso, hay una contradicción pues en los recortes se hace énfasis en datos estadísticos y la emisión de valores intenta resaltar un rostro más humano de la banca. Lo anterior expresa la dificultad de humanizar tales propósitos y la actividad económica de este tipo de organizaciones.

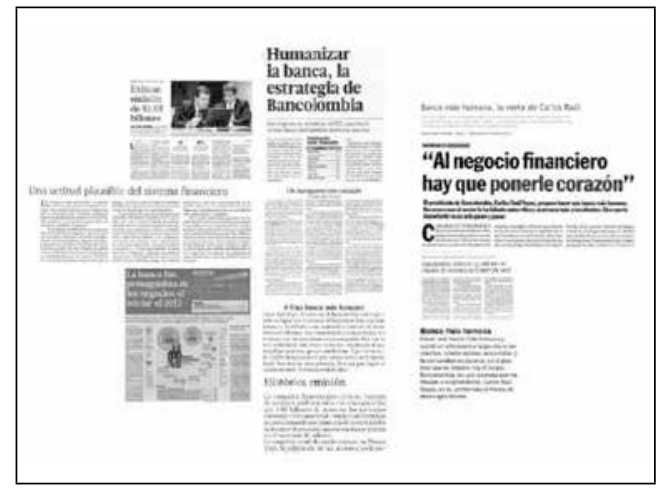

Fuente: Bancolombia (2011). Informe Gestión Empresarial Responsabilidad Corporativa, p. 2.

El uso del mapa latinoamericano sitúa y resalta a Colombia con el color amarillo que en términos semióticos hace alusión a la riqueza y la prosperidad, pero más allá de denotar esta característica de forma explícita, connota la dinámica de expansión de Bancolombia que acompaña la afirmación "somos un grupo financiero latinoamericano".

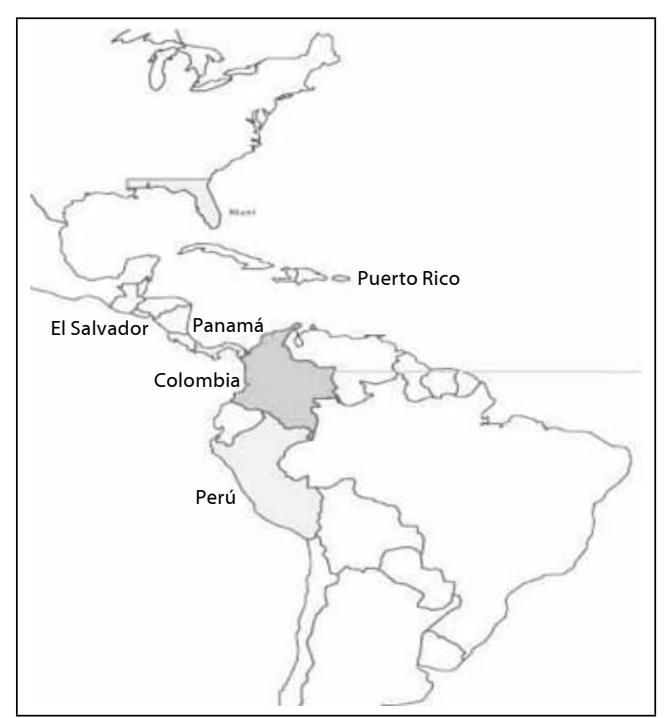

Fuente: Bancolombia (2011). Informe Gestión Empresarial Responsabilidad Corporativa, pp. 4-5.

El informe presenta imágenes que ilustran el conjunto de valores que identificarían una banca más humana. Las imágenes se caracterizan por retratar a personas que trabajan en la corporación; los rostros del "Yo de la organización” están compuestos por un fondo que hace referencia a lugares o aspectos emblemáticos de las ciudades donde Bancolombia tiene sucursales, y además resaltan por estar dentro de la forma del logo de la organización, lo cual enmarca al sujeto dentro de la imagen de la empresa y lo vincula al sentido de lo que el informe nombra como "una nueva forma de expresarnos", lo que se ha denominado como el diccionario del Grupo Bancolombia.

Entre estas imágenes, hay una que causa varios interrogantes en el sentido de su notoria escenificación, ya que sorprende la imagen de una plaza de mercado en la que los productos están muy ordenados y la mujer que atiende personi- 
fica al vendedor ideal, pero escapa a las características de un vendedor en una plaza de mercado colombiana. Nótese entre otras cosas la limpieza de la imagen, la letra de los avisos y los recipientes de los granos llenos hasta el tope.

En este sentido, el informe en su mayoría presenta imágenes muy escenificadas que cons- truyen una narración sobre la identidad; fotos escogidas y planeadas que no son imágenes documentales que captan un momento, sino imágenes que construyen un momento con poses, vestuarios y escenografías que buscan agradar al lector.
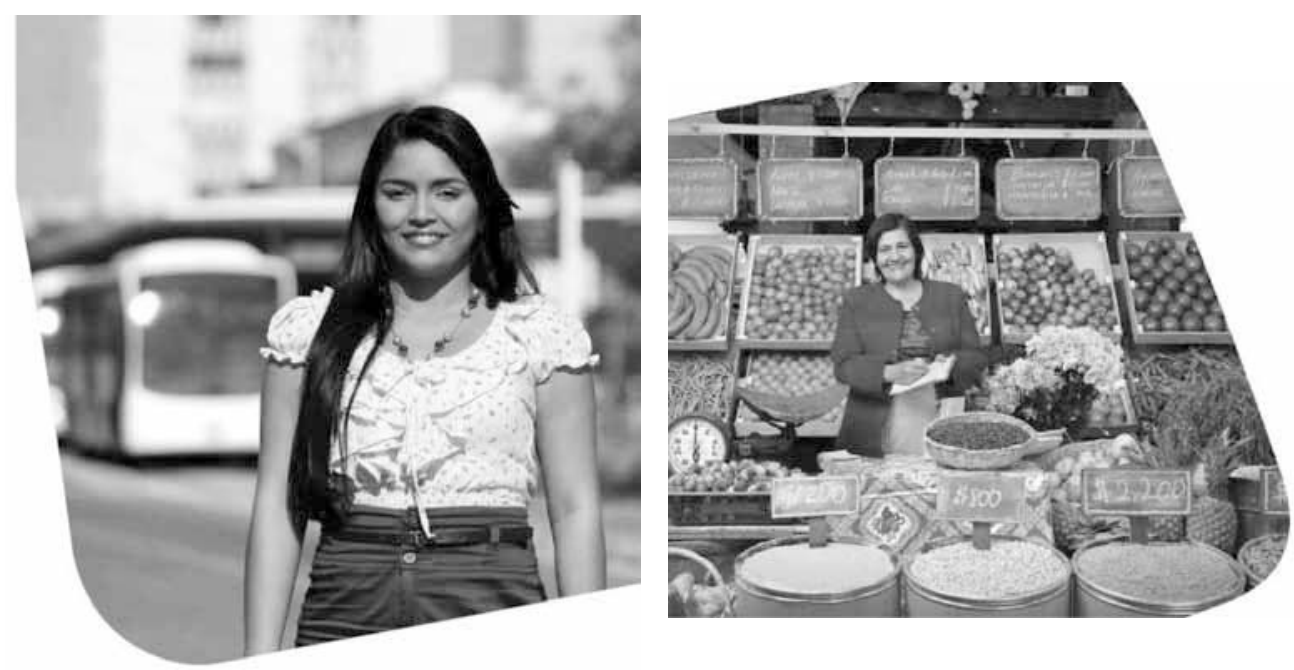

Fuente: Bancolombia (2011). Informe Gestión Empresarial Responsabilidad Corporativa, pp. 18-21,

Una foto de la Junta Directiva de Bancolombia muestra las caras de quienes piensan y dirigen las operaciones de la corporación. Por su edad y aspecto, estas personas reflejarían la experiencia. Al igual que las imágenes anteriores, esta también ha sido planeada y para su toma ha sido necesario juntar a los sujetos que la conforman en un momento en el que ellos no están ejerciendo sus funciones. ¿Cuánto puede costar el tiempo que estas personas dedicaron a la toma de esta foto? ¿En qué momento pudieron estar juntos y dispuestos todos?

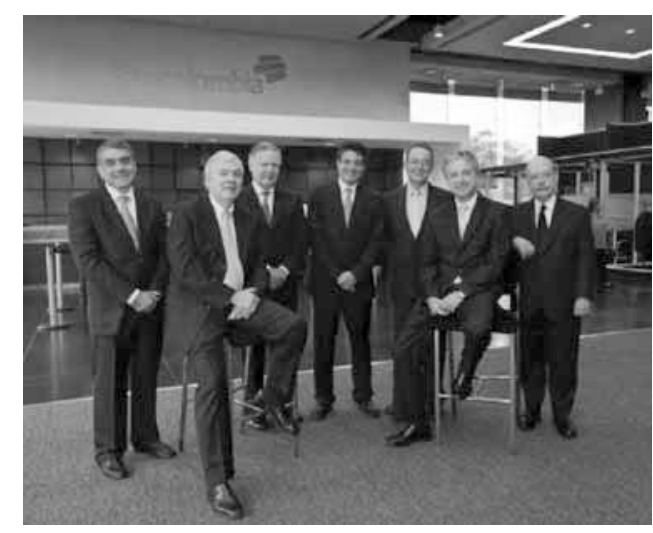

Fuente: Bancolombia (2011). Informe Gestión Empresarial Responsabilidad Corporativa, pp. 32-33. 
A continuación, el informe presenta un relato construido a partir de imágenes que ilustran algunos de los valores que son la base para una banca más humana, pero en las que son notorios la construcción del encuadre y los escenarios que en su mayoría retratan situaciones simples demasiado perfectas en las que el aspecto fotográfico bien logrado, resalta la intención por destacar un conjunto de ideales; como en la imagen de una recién nacida dormida con un brazalete con el nombre de Esperanza que guarda una relación directa con el texto escrito acerca del "Respeto por los inversionistas".

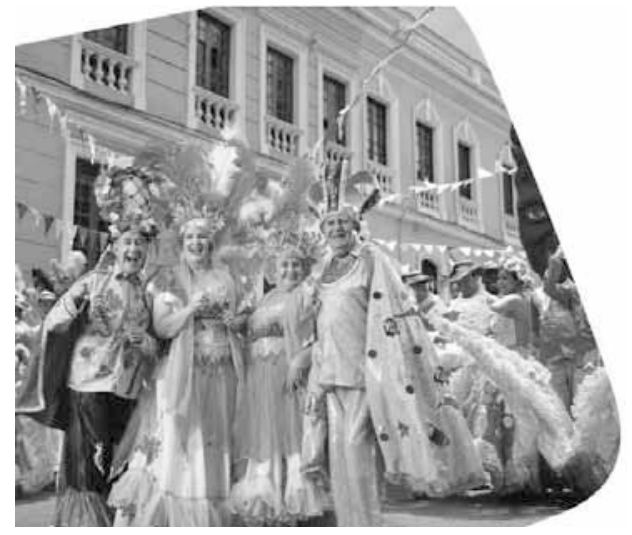

Fuente: Bancolombia (2011). Informe Gestión Empresarial Responsabilidad Corporativa, pp. 78-79.
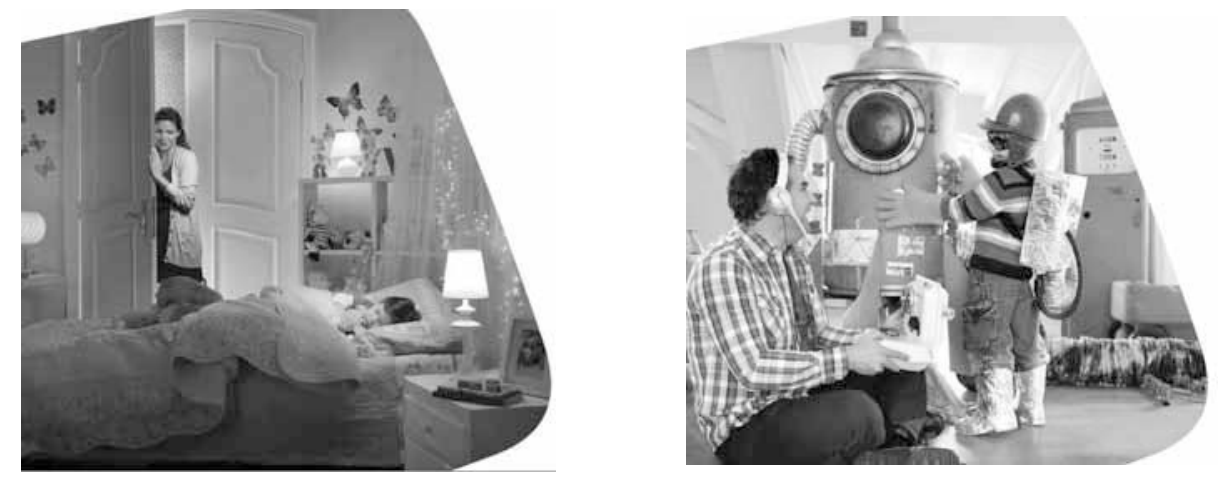

Fuente: Bancolombia (2011). Informe Gestión Empresarial Responsabilidad Corporativa, pp. 28-29.
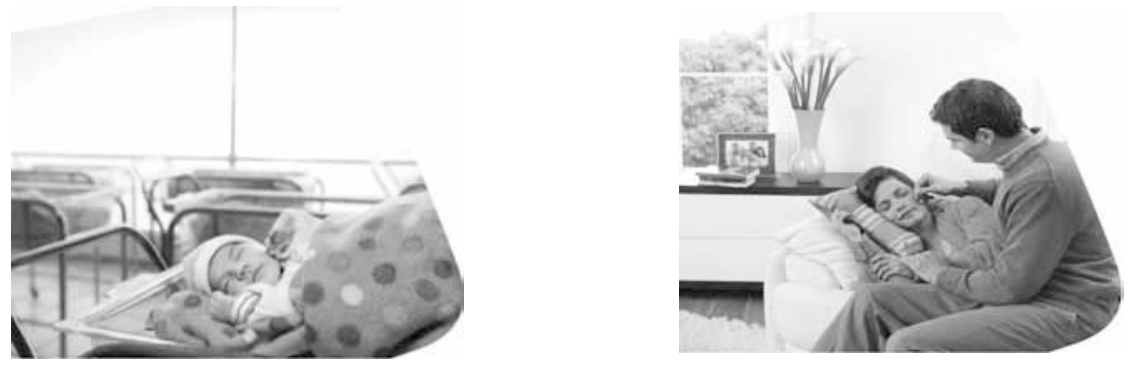

Fuente: Bancolombia (2011). Informe Gestión Empresarial Responsabilidad Corporativa, pp. 84-85, 110-111. 
El relato de este informe lo cierra una imagen compuesta en la que el verde sirve de fondo para construir un logo hecho de personas y de colores que identifican la corporación, una ban- ca hecha por humanos. Por último, el fondo de la imagen que dio inicio a este informe se retoma para presentar y enfatizar en los valores de lo que sería una banca más humana.
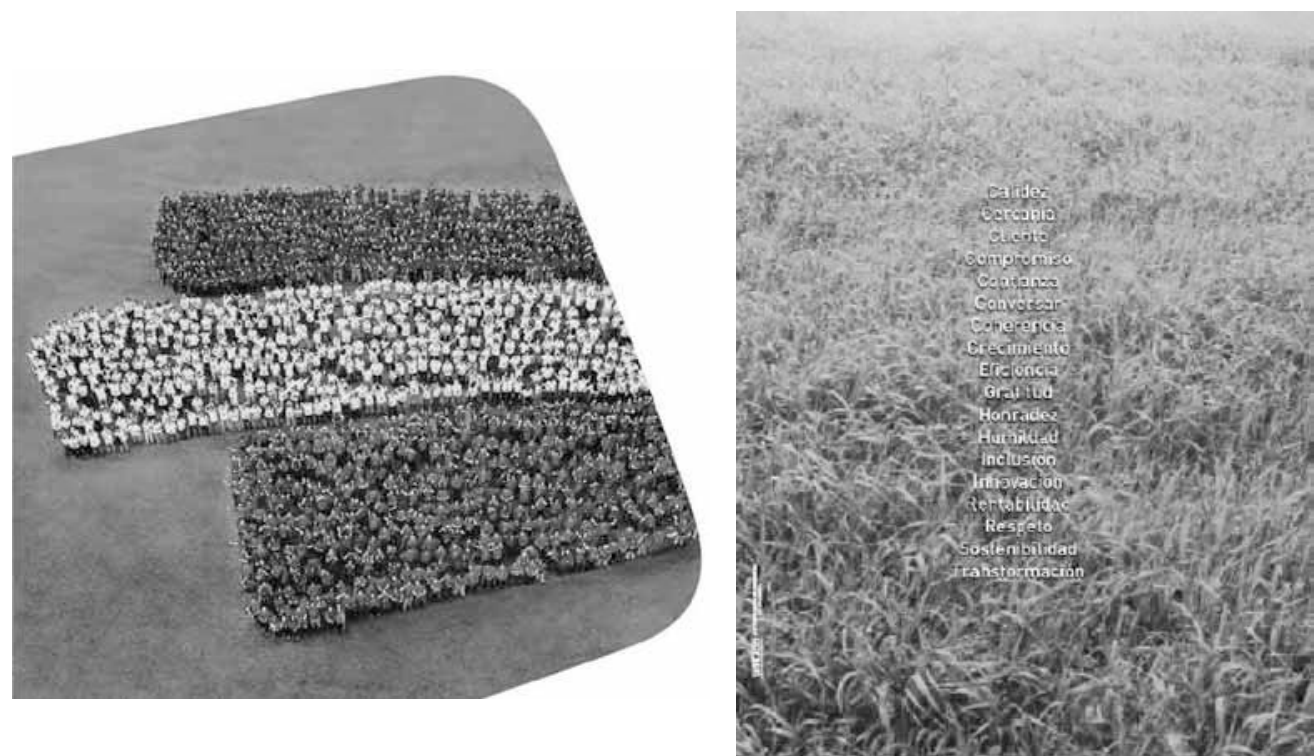

Fuente: Bancolombia (2011). Informe Gestión Empresarial Responsabilidad Corporativa, pp. 152-153, 339.

El caso de Bancolombia permite evidenciar lo sostenido por Lipovetsky (2000) en relación con la denominada ética de los negocios, terreno que sitúa a la empresa en el teatro de la vida cotidiana en donde coexiste bajo la forma de 'Ciudadano Corporativo' dotado de alma que la hace ver como ciudadano 'socialmente responsable' (Lipovetsky, 2000). De esta manera, la tabla 1 reseña el conjunto de enunciados que a lo largo del informe de Bancolombia apuntan a establecer, por un lado, la concepción del "Yo ideal" por parte la empresa, una dimensión de sí ideal, una suerte de identificación sin mediación simbólica alguna; por otro lado, resalta la variedad de valores que asume como propios de su praxis, valores que gravitan en el entorno institucional al cual se ancla, se sujeta Bancolombia.

Por lo anterior, se puede proponer un isomorfismo entre los ICA y el estado del espejo lacaniano: así como el sujeto humano se ve "frente a una imagen reflejada que constituye, y además organiza, su visión del mundo" (Elliott, 1995, p. 170), en igual movimiento, la organización adquiere de los ICA una imagen ortopédica a partir de la cual se funda su "yo" como organización económica moderna que la diferencia de otros no-yo organizacionales. 
INFORMES CONTABLES ANUALES / J. CUEVAS / 417

\begin{tabular}{|c|c|c|}
\hline Categorías & Página & Contenido \\
\hline \multirow{4}{*}{ 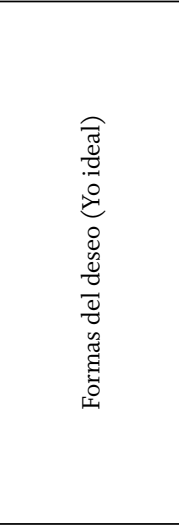 } & 9 & $\begin{array}{l}\text { Nuestra misión no es otra que la de garantizar un buen cuidado de los recursos que } \\
\text { captamos del público y la de ocuparnos de apoyar los proyectos. } \\
\text { Los retos están ahí y debemos estar dispuestos a buscar alternativas para cada uno } \\
\text { de nuestros clientes, de manera que podamos impulsar a los diferentes sectores de la } \\
\text { población y contribuyamos desde nuestro rol de banqueros, a disminuir la desigualdad } \\
\text { social y generar un desarrollo sostenible para la ciudadanía. }\end{array}$ \\
\hline & 10 & $\begin{array}{l}\text { Porque el reto es cumplir esa promesa que hoy le estamos haciendo a nuestros clientes. } \\
\text { Queremos ser más para servir mejor }\end{array}$ \\
\hline & 13 & $\begin{array}{l}\text { Estamos convencidos de que el Grupo Bancolombia continuará creciendo y jugará un papel } \\
\text { fundamental en el desarrollo de los países de la región en los próximos años, con el apoyo } \\
\text { de todos y cada uno de ustedes. }\end{array}$ \\
\hline & 30 & $\begin{array}{l}\text { Ser una organización comprometida con la excelencia, que satisface las necesidades } \\
\text { financieras de los clientes con soluciones integrales e innovadoras }\end{array}$ \\
\hline \multirow{19}{*}{ 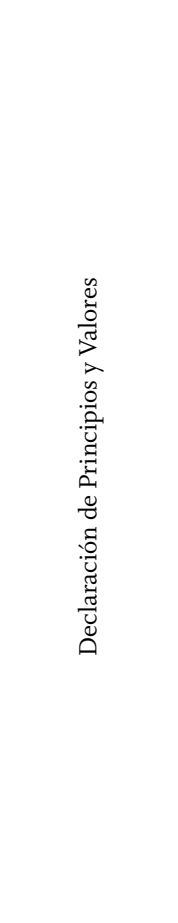 } & 10 & La primera $\mathrm{R}$ es la reputación \\
\hline & 10 & La segunda $\mathrm{R}$ es la responsabilidad \\
\hline & & Respeto \\
\hline & 0 & Calidez \\
\hline & 23 & Cercanía \\
\hline & & Inclusión \\
\hline & 26 & Cercanía \\
\hline & 42 & Compromiso \\
\hline & 43 & Confianza \\
\hline & 76 & Crecimiento \\
\hline & 83 & Gratitud \\
\hline & 89 & Honradez \\
\hline & \multirow{4}{*}{93} & Cercanía \\
\hline & & Calidez \\
\hline & & Inclusión \\
\hline & & Respeto \\
\hline & 96 & Humildad \\
\hline & 108 & Innovación \\
\hline & 109 & Rentabilidad \\
\hline
\end{tabular}

Tabla 1. Matriz de análisis textual del yo Bancolombia

Fuente: elaboración propia

Los informes anuales constituyen una imagen (forma) que in-forma (da forma) a la organización acerca de sí y guía su desarrollo, como lo vislumbran John P. Muller y William J. Richardson (1982) para el caso del sujeto humano en la perspectiva del estadio del espejo lacaniano. La imagen que los ICA proyectan de la organización, transforma a la organización mediante un proceso de identificación con esa imagen que, en términos lacanianos, constituye de forma 
ortopédica al "yo". Los informes anuales, vistos de esta manera, conforman una imagen unificada de la organización e instituyen por esta vía al "yo" de la organización como un objeto que le es dado y a partir del cual se despliega.

\section{La institución del "yo" organizacional en los informes contables anuales (ICA): un isomorfismo con el estadio del espejo lacaniano}

Con base en la exploración realizada, se propone un isomorfismo entre los informes anuales y el espejo lacaniano. Los ICA, siguiendo el análisis propuesto por Pierre Legendre (2008a, 2008b, 2008c) alrededor de la cultura occidental, funcionan como un montaje lingüístico encargado de instituir una relación de identidad, la imagen especular de la organización moderna. Como se vio, los ICA agrupan el conjunto de imágenes (yo') con las cuales la organización (yo) se identifica, imágenes a las que se articula y a partir de las cuales la organización se gestiona. Dicho de otro modo, los ICA constituyen una formación discursiva, una superficie de inscripción para el campo imaginario en donde emerge el "yo" de la organización.

La organización se descubre a sí misma en una imagen externa. Al trazar los límites de la organización, lo que la organización es (Hines, 1988), los ICA funcionan como las imagos en el sujeto que le permiten a este, por medio de la identificación, reconocer al otro como un otro (Chiesa, 2007, p. 28). En esta medida, debe tenerse en cuenta que, así como en el estadio del espejo se instituye la distinción entre "yo" y no-yo, los informes anuales bajo el poder constitutivo de la contabilidad demarcan qué es organización y qué no es organización (Larrinaga \& Carrasco, 1996).

Las imágenes en los ICA se proyectan como retratos en una casa, una forma de exhibir lo que se es, de visibilizar la relación de identidad. Esto se refuerza con el uso de los marcadores discursivos, los deícticos, que permiten en el discurso rastrear la posición de los enunciadores, su subjetividad discursiva. Así, se pudo advertir en el discurso de los ICA una marcada tendencia al uso de la primera persona de plural, a partir de lo cual se señalan características y cualidades alrededor de la identidad de la organización, es decir, una dimensión sujeta a lo subjetivo. En algunos casos, se observa un deslizamiento constante entre al "somos" y el "es", es decir, si se es "nosotros" o se es "él". No obstante, desde este ejercicio de aprehensión discursiva de la dimensión imaginaria del "yo", se refuerza la existencia en el informe de ideales yoicos, es decir, la existencia de un plano imaginario gobernado por el yo ideal. Este plano del yo ideal en los ICA se refuerza, en gran medida, por la declaración de principios y valores en los que las empresas buscan basar su identidad. En consecuencia, y como se observa en el anexo, hay un amplio despliegue de imágenes convocadas por el investimiento libidinal, es decir, son imágenes en las que la organización se identifica y se reconoce, que permiten configurar el campo imaginario en el que el "yo" de la organización se instituye.

De esta manera, es posible proponer los ICA como una unidad imaginaria. Estos permiten, siguiendo una concepción ontológica, 
proyectar el ser de la organización hacia afuera y desplazarlo en el tiempo del discurso. La ex-sistencia de la que habla Martin Heidegger (2001) y que es asumida por el psicoanálisis lacaniano, puede ser oteada en el caso de la organización por medio de los ICA como se hizo con el informe analizado. Por tanto, así como el “yo" es un efecto de las imágenes (Homer, 2005, p. 25), la organización como organización económica moderna es un efecto de la imagen de los informes anuales, de lo uno que instituyen.

No obstante, debe subrayarse la naturaleza ficcional del "yo" de la organización. Esto significa que la imagen reflejada por los ICA constituye una "armadura" en la que se gest(ion)a una identidad alienada en la que, como ocurre con el sujeto humano en la fase del espejo, la organización se precipita (la identificación con la imagen especular) y anticipa una forma (imaginaria) de ser-en-el-mundo. Así, la organización se descubre en una imagen externa: los ICA.

Los ICA ensamblan la unidad imaginaria de la organización. Cuando la organización se toma por sí misma, a partir de la imagen proyectada e instituida por la contabilidad en los ICA, se despliega y se repliega tras este lazo especular, resultaría oportuno admitir que el "yo ha nacido" (Assoun, 2003). En consecuencia, y retomando lo anterior, se pueden proponer algunos rasgos para pensar el isomorfismo que se presenta entre los ICA y el estadio del espejo lacaniano como sigue:

\begin{tabular}{ll}
\hline \multicolumn{1}{c}{ Estadio del espejo } & \multicolumn{1}{c}{ Informes contables anuales } \\
\hline Forma que in-forma & Produce la imagen de la realidad organizacional \\
Precipitación imaginaria & Imagen delineada por el dominio de los valores financieros \\
De la experiencia fragmentada a la imagen & Capacidad de síntesis y homogeneización de los hechos y circunstancias \\
unificada (anticipación) & socioorganizacionales \\
& $\begin{array}{l}\text { Imágenes ejemplarizantes de los cálculos contables; imágenes del mundo } \\
\text { socioambiental en el que se proyecta la organización; formas del deseo de }\end{array}$ \\
Identificaciones - yo ideal & $\begin{array}{l}\text { la organización (empresa en marcha) } \\
\text { Régimen de visibilización (tecnología que modifica el mundo mediante la } \\
\text { visibilización de los sucesos) }\end{array}$ \\
La organización como campo cognoscible/calculable/gestionable por \\
Yo como campo imaginario & medio de las imágenes contables \\
\hline
\end{tabular}

Tabla 2. Isomorfismo Estadio del espejo/informes contables anuales Fuente: elaboración propia

\section{Conclusiones provisionales}

¿Cómo son usados los informes contables anuales para instituir al "yo" de la organización económica moderna en el marco de la contemporaneidad? La concepción del sujeto sujetado al lenguaje, por una parte, y la crisis que se cuece en la cultura contemporánea, por la otra, se tornan puntos nodales de la comprensión de la relación establecida entre la contabilidad como práctica social e institucional y las organizaciones. En consecuencia, si bien devienen de una 
estructura del cálculo racional, en la contemporaneidad, los ICA se han potenciado como un espacio en que se instituye la identidad organizacional, no solo como agente racional (los estados financieros cumplirían este propósito), sino también otro tipo de discursos que buscan producir la identidad organizacional: gráficos, imágenes, lemas, epígrafes, etc. En este sentido, la contabilidad configura un entramado donde se ensambla y se proyecta la identidad organizacional, donde tiene ocurrencia la institución y afirmación del "yo" organizacional como un efecto del lenguaje. Los ICA instituyen una forma ortopédica, una imagen que in-forma $a$ la organización y la hace advenir al campo de lo visible como una organización racional, responsable y moderna.

Al plantear que "la organización económica moderna no existe" lo que se evidencia entonces es el proceso de su ensamblaje, pues en modo alguno es una realidad positiva o cuenta con una esencia constitutiva. La sociedad y, en ella, los sujetos y las organizaciones son discursivamente producidos. Es necesario contar con sistemas discursivos, como el contable, para producir las relaciones basadas en la lógica de la identidad. Esto no indica que el discurso esté desprovisto de efecto alguno; por el contrario, la capacidad performativa del discurso moldea las relaciones entre los sujetos y su cultura. Esta es la materialidad del discurso, que entre otras cosas puede ser advertida en el sintagma "Una banca más humana”, a partir del cual se establece una relación con la identidad.

Los ICA determinan la configuración de la estructura imaginaria y simbólica de la organización. Si la crisis del sujeto se lee como el tránsito de la concepción moderna, una concepción de sujeto centrado en la culpa (el sujeto neurótico) y en el rechazo a la configuración de la realidad (el sujeto crítico), a una concepción que reforma la idea del sujeto al situarlo en un terreno psicótico (el sujeto esquizofrénico), puede ser trasladada a la organización, a partir de un ejercicio analítico y tratando de resguardar las proporciones que tal análisis implica, en atención de la mención de Freud acerca de que la cultura trabaja con los mismos elementos que los seres humanos (Legendre, 2008c). En consecuencia, bajo esta mirada, resulta importante problematizar, en un sentido foucaultiano, la forma en la que las organizaciones se visibilizan y hacen lazo social. Si se acepta que la organización adviene al teatro social con el mismo signo del sujeto sujetado al lenguaje, corresponde entonces advertir los efectos sociales e institucionales de legitimar la inscripción de una imagen ideal ${ }^{20}$ en la superficie de los ICA, aun sabiendo que bajo ella todo arde.

\section{Referencias}

Agamben, Giorgio (2009). Signatura rerum. Sobre el método. Buenos Aires: Adriana Hidalgo.

Archel-Domench, Pablo (2007a). Discurso contable, ideología e informes anuales: un enfoque interpretativo. Revista Contaduría Universidad de Antioquia, 51, 41-64. Disponible en: https://aprendeenlinea.udea.edu.

20 Primacía del yo ideal sobre los ideales del yo, síntoma del malestar en la cultura contemporánea. 
co/revistas/index.php/cont/article/viewFile/2147/1749

Archel-Domench, Pablo (2007b). Teoría e investigación crítica en contabilidad: un estudio de caso. Madrid: Asociación Española de Contabilidad y Administración de Empresas, AECA. Disponible en: http://www.aeca.es/ tienda/m77.pdf

Assoun, Paul-Laurent (2003). Lacan. Buenos Aires: Amorrortu.

Bailly, Lionel (2009). Lacan (A Beginner's Guide). London: Oneworld Publications.

Bancolombia (2011). Informe Gestión

Empresarial Responsabilidad

Corporativa. Disponible en: http://www.grupobancolombia. com/contenidoCentralizado/ informacionEmpresarial/ relacionInversionistas/gobiernoCorporativo/ resultadosFinancieros/resultadosAnuales/ anuales/2011/Informe2011GesEmp.pdf

Beckett, Samuel (2006). El innombrable. Madrid: Alianza Editorial.

Burchell, Stuart; Clubb, Colin \& Hopwood, Anthony (1985). Accounting in its Social Contexts: towards a History of Value Added in the United Kingdom. Accounting, Organizations and Society, 10 (4), 381-413.

Burchell, Stuart; Clubb, Colin; Hopwood, Anthony; Hughes, John \& Nahapiet, Janine (2005). The Roles of Accounting in Organizations and Society. En Norman Belding Macintosh \& Trevor Hopper (eds.). Accounting, the Social and the Political: Classics, Contemporary and Beyond, 5-12. Amsterdam: Editorial Elsevier.
Burke, Peter (2001). Visto y no visto: el uso de la imagen como documento histórico. Barcelona: Crítica.

Chiesa, Lorenzo (2007). Subjectivity and Otherness. A Philosophical Reading of Lacan. Cambridge, Massachusetts: The MIT Press.

Crosby, Alfred W. (1998). La medida de la realidad: la cuantificación y la sociedad occidental, 1250-1600. Barcelona: Grijalbo Mondadori.

Cuevas, John Jairo (2012). El desencantamiento de las imágenes del mundo: apuntes a partir de la sociología clásica para una mirada sobre el individuo y la empresa contemporáneos. Revista Economía, Gestión y Desarrollo, 13, 155-179. Disponible en: http://revistaeconomia.puj.edu.co/html/ articulos/Numero_13/CUEVAS.pdf

Dasuky-Quiceno, Samir Ahmed (2010). El discurso del amo: de Hegel a Lacan. Escritos, 18 (40), 100-124.

Davison, Jane (2002). Communication and Antithesis in Corporate Annual Reports: A Research Note. Accounting, Auditing \& Accountability Journal, 15 (4), 594-608.

Davison, Jane (2007). Photographs and Accountability: Cracking the Codes of an NGO. Accounting, Auditing \& Accountability Journal, 20 (1), 133-158.

Davison, Jane (2011a). Barthesian Perspective on Accounting, Communication and Visual Images of Professional Accountancy. Accounting, Auditing \& Accountability Journal, 24 (2), 250-283.

Davison, Jane (2011b). Paratextual Framing of the Annual Report: Liminal Literary Conventions and Visual Devices. Critical Perspective on Accounting, 22 (2), 118-134. 
Davison, Jane; McLean, Christine \& Warren, Samantha (2012). Exploring the Visual in Organizations and Management. Qualitative Research in Organizations and Management: An International Journal, 7 (1), 5-15

Davison, Jane \& Skerratt, Len (2007). Words, Pictures and Intangibles in the Corporate Report. Edinburgh: Institute of Chartered Accountants of Scotland, ICAS.

Deleuze, Gilles \& Guattari, Félix (1994). Mil Mesetas. Capitalismo y esquizofrenia. Valencia: Pre-Textos

Dor, Joel (1994). Introducción a la lectura de Lacan: el inconsciente estructurado como lenguaje en psicoanálisis. México: Gedisa.

Dufour, Dany-Robert (1990). Les mystères de la trinité. Paris: Gallimard.

Dufour, Dany-Robert (2005). Lacan y el espejo sofiánico de Böehme. México: Fundación Universitaria de Derecho y Administración Pública, Fundap.

Dufour, Dany-Robert (2007). Crítica de los postmodernidad. Gobernancia y democracia. Santiago de Cali: Universidad del Valle.

Elliott, Anthony (1995). Teoría social y psicoanálisis en transición. Sujeto y sociedad de Freud a Kristeva. Buenos Aires: Amorrortu.

Fink, Bruce (1999). A Clinical Introduction to Lacanian Psychoanalysis: Theory and Technique. Cambridge, Massachusetts: Harvard University Press.

Freud, Sigmund (1988). El malestar en la cultura. Bogotá: Alianza Editorial.

Fuentes-Ruiz, Pilar de (1993). Legitimación y contabilidad ambiental. Revista Española de Financiación y Contabilidad, REFC, 23 (75),
317-332. Disponible en: http://www.aeca. es/pub/refc/articulos.php?id=0462

Gaufey, Guy le (2001). El lazo especular. Un estudio transversal de la unidad imaginaria. México: Editorial Psicoanalítica de la Letra, EPEELE.

Gómez-Villegas, Mauricio (2009). Los informes contables externos y la legitimidad organizacional con el entorno: estudio de un caso en Colombia. Revista Innovar, 19 (34), 147-166. Disponible en: http://www. revistas.unal.edu.co/index.php/innovar/ article/view/21611/34904

Hines, Ruth D. (1988). Financial Accounting: In Communicating Reality, We Construct Reality. Accounting, Organizations and Society, 13 (3), 251-261. Disponible en: https://www2.le.ac.uk/departments/ management/documents/undergraduatecourses/a-f-preparatory-reading-hines Homer, Sean (2005). Jacques Lacan. Abingdon, United Kingdom: Routledge.

Hopwood, Anthony (1996). Making Visible and the Construction of Visibilities: Shifting Agendas in the Design of the Corporate Report: Introduction. Accounting, Organizations and Society, 21 (1), 55-56.

Husillos-Carqués, Francisco Javier (2004). Información medioambiental, contabilidad y teoría de la legitimación. Empresas cotizadas: 1997-1999. Documento de trabajo 07/04. Madrid: Universidad Carlos III de Madrid. Disponible en: http://gredos.usal.es/jspui/ bitstream/10366/75250/1/DAEE_07_04_ Informaci\%C3\%B3nMedioambiental.pdf Jameson, Fredric (1977). Imaginary and Symbolic in Lacan: Marxism, Psychoanalytic 
Criticism, and the Problem of the Subject. Yale French Studies, 55/56, 338-395. Disponible en: https://aklatangbayan.files. wordpress.com/2013/02/jameson-fredricimaginary-and-symbolic-in-lacan.pdf

Lacan, Jacques (1977). Lo simbólico, lo imaginario y lo real. Revista Argentina de Psicología, 22, 11-27. Disponible en: http://www. con-versiones.com.ar/textos/nota0237.doc

Lacan, Jacques (1984). Escritos I. México: Siglo XXI.

Lacan, Jacques (1998). The Four Fundamental Concepts of Psychoanalysis. New York: W.W. Norton \& Company.

Laclau, Ernesto (1990). New Reflections on the Revolution of Our Time. London: Verso.

Larrinaga-González, Carlos \& Carrasco-Fenech, Francisco (1996). El poder constitutivo de la contabilidad: consideraciones sobre la cuestión medioambiental. En Ensayos sobre contabilidad y economía: en homenaje al profesor Ángel Sáez-Torrecilla, vol. 2, 65-84. Madrid: Ministerio de Economía y Competitividad, Instituto de Contabilidad y Auditoría de Cuentas, ICAC.

Legendre, Pierre (2008a). Dominium mundi El imperio del Management. Buenos Aires: Amorrortu.

Legendre, Pierre (2008b). La fábrica del hombre occidental. Buenos Aires: Amorrortu.

Legendre, Pierre (2008c). Lo que Occidente no ve de Occidente. Conferencias en Japón. Buenos Aires: Amorrortu.

Lipovetsky, Gilles (2000). El crepúsculo del deber. La ética indolora de los nuevos tiempos contemporáneos. Barcelona: Anagrama.
Macintosh, Norman Belding (2002). Accounting, Accountants and Accountability: PostStructuralist Positions. Abingdon, United Kingdom: Routledge.

Martínez-Solís, María Cristina (2005). La argumentación en la dinámica enunciativa del discurso y la construcción discursiva de la identidad de los sujeto. En María Cristina Martínez-Solís (ed.). Didáctica del discurso. Argumentación y narración. Talleres, 11-22. Santiago de Cali: Cátedra UNESCO-Universidad del Valle.

Mattessich, Richard (2002). Contabilidad y métodos analíticos: medición y proyección del ingreso y la riqueza en la microeconomía y la macroeconomía. Buenos Aires: Editorial La Ley.

Miller, Peter (1994). Accounting as Social and Institutional Practice: An Introduction. En Anthony G. Hopwood \& Peter Miller (eds.). Accounting as Social and Institutional Practice, 1-39. Cambridge: Cambridge University Press.

Milner, Jean-Claude (1996). La obra clara: Lacan, la ciencia, la filosofía. Buenos Aires: Manantial.

Muller, John P. \& Richardson, William J. (1982). Lacan and language. A Reader's Guide to Écrits. New York: International Universities Press.

Nasio, Juan David (2001). La mirada en psicoanálisis. Barcelona: Gedisa.

Ogilvie, Bertrand (1988). Lacan. A formação do conceito de sujeito (1932-1949). Dulce Duque-Estrada (trad.). Rio de Janeiro: Jorge Zahar Editor. 
Panofsky, Erwin (2008). Estudios sobre iconología. Madrid: Alianza.

Pignot, E. (2012). Interpreting Virtual Knowledge Sharing with Lacan: The Goldman Sachs?

Trial. Copenhagen: Copenhagen Business School, CBS.

Preston, Alistair M.; Wright, Christopher \& Young, Joni J. (1996). Imag(in)ing Annual Reports. Accounting, Organizations and Society, 21 (1), 113-137.

Preston, Alistair \& Young, Joni J. (2000). Constructing the Global Corporation and Corporate Constructions of the Global: A Picture Essay. Accounting, Organizations and Society, 25 (4-5), 427-449.

Quattrone, Paolo (2009). Books to be Practiced: Memory, the Power of the Visual, and the Success of Accounting. Accounting, Organizations and Society, 34 (1), 85-118.

Rabaté, Jean-Michel (2011). Jacques Lacan: Psychoanalysis and the Subject of Literature. New York: Palgrave.

Ricœur, Paul (1989). Ideología y utopía. Barcelona: Gedisa.

Ricœur, Paul (1999). Historia y narratividad. Barcelona: Editorial Paidós.

Ricœur, Paul (2002). Del texto a la acción: ensayo de hermenéutica II. México: Fondo de Cultura Económica, FCE.

Ricœur, Paul (2006a). Sí mismo como otro. Madrid: Siglo XXI.

Ricœur, Paul (2006b). Teoría de la interpretación: discurso y excedente de sentido. México: Siglo XXI.

Roudinesco, Élisabeth (1993). Lacan: Esbozo de una vida, historia de un sistema de pensamiento. Buenos Aires: Fondo de
Cultura Económica, FCE. Disponible en: http://monoskop.org/images/f/f9/ Roudinesco_Elisabeth_Lacan_Esbozo_de_ una_vida_historia_de_un_sistema_de_ pensamiento.pdf

Sievers, Burkard (1999). Psychotic Organization as a Metaphoric Frame for the Socioanalysis of Organizational and Interorganizational Dynamics. Administration \& Society, 31 (5), 588-615.

Sievers, Burkard (2004). La organización sicótica como una estructura metafórica para el socioanálisis de las dinámicas organizacional e interorganizacional (primera parte). Revista de Gestión y Estrategia, 26, 83-95. Disponible en: http:// gestionyestrategia.azc.uam.mx/index. $\mathrm{php} / \mathrm{component} / \mathrm{dropfiles} /$ ?task=frontfile. download\&id $=514$

Sievers, Burkard (2005). La organización sicótica como una estructura metafórica para el socioanálisis de las dinámicas organizacional e interorganizacional (segunda parte). Revista Gestión y Estrategia, 27, 67-74. Disponible en: http://gestionyestrategia.azc. uam.mx/index.php/component/content/ category/2-general

Sievers, Burkard (2006). The Psychotic Organization: A Socio-Analytic Perspective. Ephemera, Theory \& Politics in Organization, 6 (2), 104-120. Disponible en: http://www. ephemerajournal.org/sites/default/files/62sievers.pdf

Stavrakakis, Yannis (2007). The Lacanian Left. Psychoanalysis, Theory, Politics. Edinburgh: Edinburgh University Press. 
Steiner, George (1990). Lenguaje y silencio: Ensayos sobre la literatura, el lenguaje y lo inhumano. Miguel Ultorio (trad.). Barcelona: Gedisa.

Steiner, George (1991). En el castillo de Barba Azul: Aproximación a un nuevo concepto de cultura. Barcelona: Gedisa.

Sunder, Shyam (2002). Teoría de la contabilidad y el control. Bogotá: Universidad Nacional.

Taylor, Charles Margrave (2006). Las fuentes del yo: la construcción de la identidad moderna. Barcelona: Paidós.

Žižek, Slavoj (2004). Arriesgar lo imposible. Madrid: Trotta.
- Fecha de recepción: 06 de marzo de 2015

- Fecha de aceptación: 05 de septiembre de 2015

- Disponible en línea: 01 de diciembre de 2015

\section{Para citar este artículo}

Cuevas-Mejía, John Jairo (2015). Los informes contables anuales y su papel en la institución del "yo" organizacional. Cuadernos de Contabilidad, 16 (41), 395-427. http://dx.doi.org/10.11144/Javeriana. cc16-41.icap 


\section{6 / VOL. 16 / NO. 41 / MAYO-ACOSTO 2015}

\section{Anexo}

\begin{tabular}{|c|c|c|c|c|c|c|}
\hline \multirow{3}{*}{ 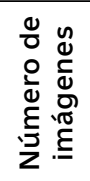 } & \multicolumn{6}{|c|}{ Bancolombia } \\
\hline & Imágenes & Epígrafes & $\begin{array}{c}\text { Cuadro } \\
\text { con cifras } \\
\text { ejemplarizantes }\end{array}$ & $\begin{array}{l}\text { Cuadros premios } \\
\text { reconocimientos }\end{array}$ & $\begin{array}{c}\text { Imágenes } \\
\text { con cifras } \\
\text { ejemplarizantes }\end{array}$ & Gráfico \\
\hline & 47 & 0 & 42 & 0 & 0 & 27 \\
\hline
\end{tabular}

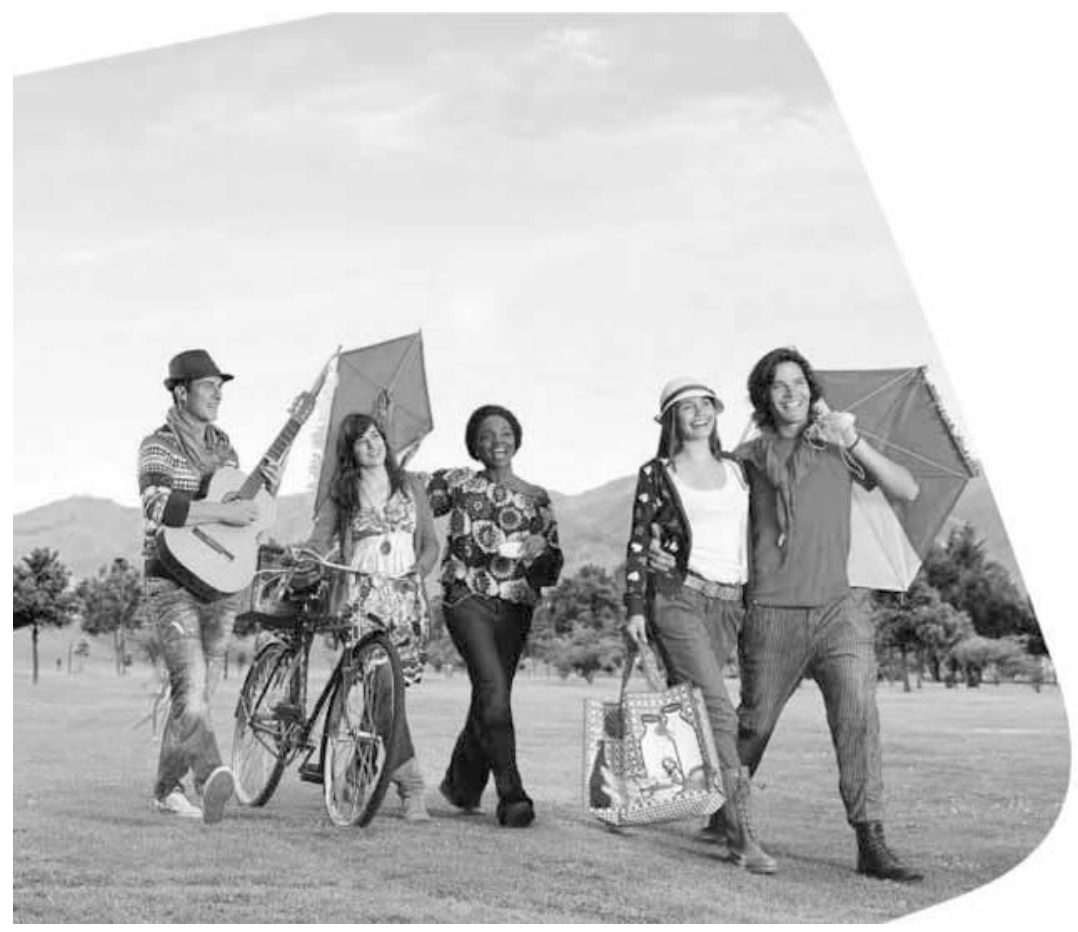

Figura 1. Ejemplo de imágenes

Fuente: Bancolombia (2011). Informe Gestión Empresarial Responsabilidad Corporativa, pp. 90-91

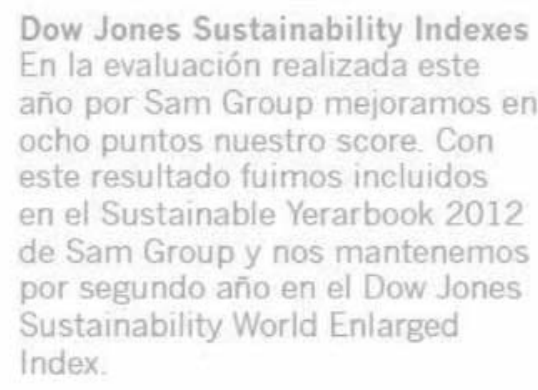

Figura 2. Ejemplo cuadro con cifras ejemplarizantes

Fuente: Bancolombia (2011). Informe Gestión Empresarial Responsabilidad Corporativa, p. 130 


\section{Estructura Organizacional}

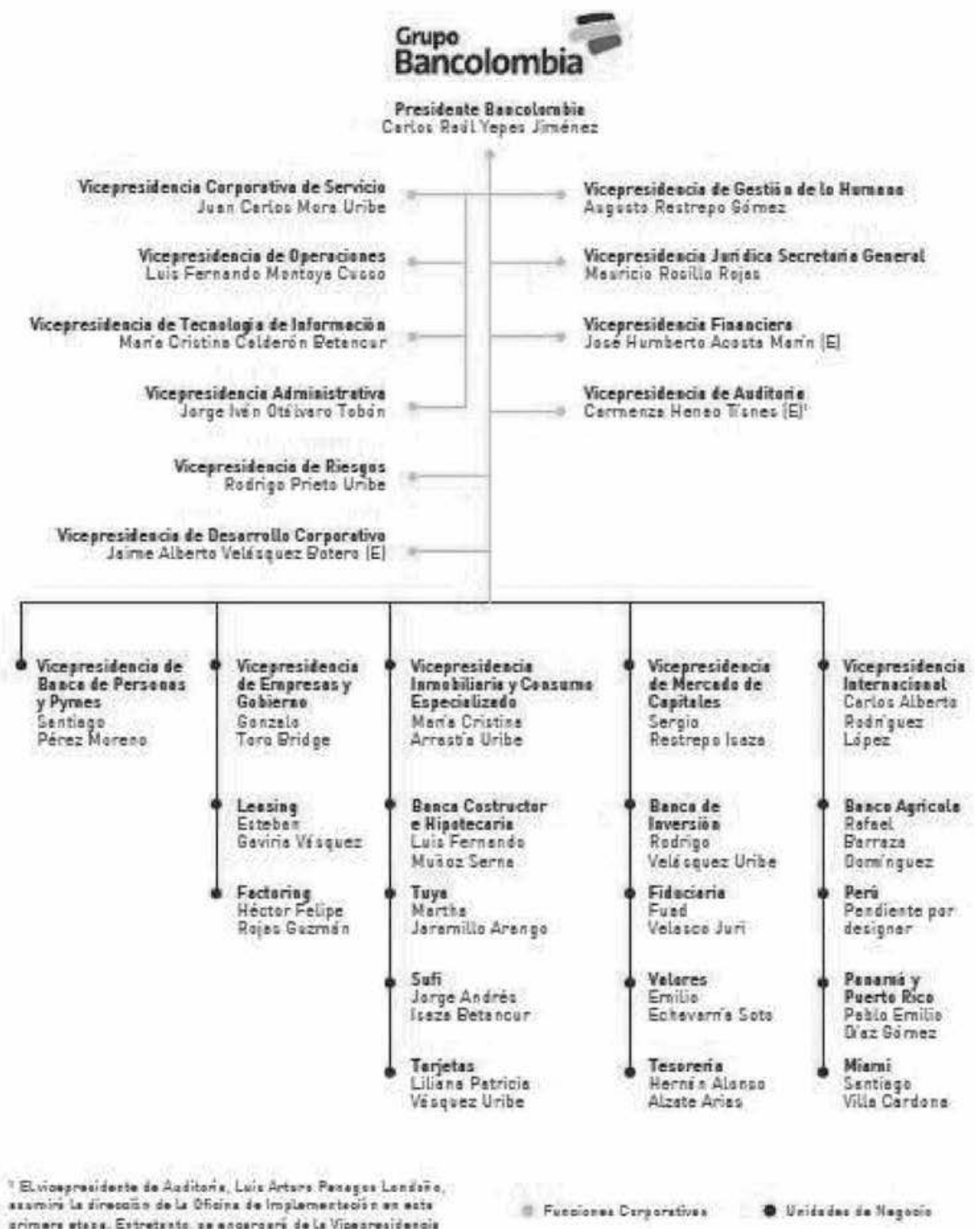

Figura 3. Ejemplo gráficos

Fuente: Bancolombia (2011). Informe Gestión Empresarial Responsabilidad Corporativa, p. 34 
